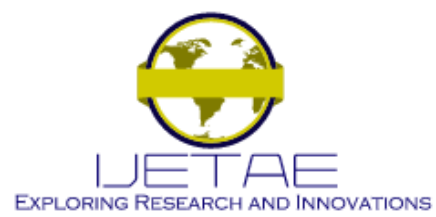

International Journal of Emerging Technology and Advanced Engineering

Website: www.ijetae.com (ISSN 2250-2459, ISO 9001:2008 Certified Journal, Volume 10, Issue 11, November 2020)

\title{
Assessment and Implementation of Environmental Flows to Restore River Gomti- a Tributary of Ganga, India
}

\author{
Ravindra Kumar \\ Partner, WWF-India, New Delhi, based at Lucknow, India
}

\begin{abstract}
Environmental flows in rivers are essential to maintain their natural regime, purify themselves, sustain aquatic life and vegetation, recharge groundwater and support livelihoods. Rivers play their role in people's cultural and spiritual lives. These functions are possible with a suitable e-flow regime. This paper aims to quantify E-Flows for alluvial river Gomti- a tributary of river Ganga, at upstream and downstream of Lucknow City, at Sultanpur and at Jaunpur. These E-flow sites were chosen on the basis of homozonation study of Gomti Basin. Two methodsHydrological consideration and holistic approach: Building Block Methodology has been employed for assessing the Eflows at four sites falling in middle and lower zone of the Gomti Basin.

The two set of E-Flows obtained have been compared with observed flows and virgin flows limits to visualize the implications of implementation plan for normal maintenance year and drought year. Considering Gomti basin water plan for 2045 while trying to meet future sectoral water demand and managing e-flows minimum allocation, the paper argues for e-flows implementation by participatory wetland conservation and improvise agricultural water use efficiency. Summary of investment plan in Gomti Basin to manage demand and supply of water optimally including minimum e-flows in Gomti river. Freed water from agriculture may be diverted into river Gomti from irrigation canal systems, offtaking from Sharda and Ghaghara rivers passing through the Gomti basin.

It is found that recommended monthly E-flows for Mehndighat is higher than the observed flows and even more than virgin flow volume except in the month of July. At Fuslauna site E-flows are higher than estimated virgin and observed flow for the months of January to June and for rest of the months July to December, E-flows values are within virgin/observed flow volume limits. Hence to implement Eflows in Gomti river at Fusluana site, additional water from Sharda Sahayak Feeder, through Gomti escape has to be released for lean flow months January to June. Augmentation of flows in Gomti river is recommended by increasing base flows contribution particularly during lean flow months.

For Sultanpur and Jaunpur sites required e-flows are almost twice higher than the present day flows in Gomti river. E-flows for Gomti river at Jaunpur is higher than the virgin flow for the month of January to June, estimated at Maighat a d/s CWC site below Jaunpur.
\end{abstract}

Alternatively, based on MOWR guidelines (as issued in case of Ganga river) considering only hydraulic perspective, minimum E-Flows for Gomti river at Lucknow, Sultanpur, Jaunpur and Maighat has been calculated. E-Flow estimates for Lucknow comes to $15.02 \mathrm{~m}^{3} / \mathrm{s}, 7.70 \mathrm{~m}^{3} / \mathrm{s}$ and $3.41 \mathrm{~m}^{3} / \mathrm{s}$ during monsoon (June to Sep.), non lean flow month (Oct \& Nov.) and lean flow months Dec to May respectively. For Sultanpur site $42.70 \mathrm{~m}^{3} / \mathrm{s}, 23.73 \mathrm{~m}^{3} / \mathrm{s}$ and $10.26 \mathrm{~m}^{3} / \mathrm{s}$ and for Jaunpur site $44.94 \mathrm{~m}^{3} / \mathrm{s}, 29.22 \mathrm{~m}^{3} / \mathrm{s}$ and $11.28 \mathrm{~m}^{3} / \mathrm{s}$ has been obtained for the same period.

E-flows assessed applying BBM, monthly discharge ranges are for Mehndighat $40-415 \mathrm{~m}^{3} / \mathrm{s}$, Aqueduct site $40-58 \mathrm{~m}^{3} / \mathrm{s}$, Sultanpur $92-950 \mathrm{~m}^{3} / \mathrm{s}$ and for Jaunpur site $100-795 \mathrm{~m}^{3} / \mathrm{s}$. During wet months flushing requirement for two weeks period is $310 \mathrm{~m}^{3} / \mathrm{s}$ at Lucknow, $1370 \mathrm{~m}^{3} / \mathrm{s}$ at Sultanpur and $2450 \mathrm{~m}^{3} / \mathrm{s}$ for Jaunpur. This peak flow appears possible at Lucknow due to barrage but difficult to implement at Sultanpur and Jaunpur. Although ever maximum discharge observed had been at Lucknow $916.97 \mathrm{~m}^{3} / \mathrm{s}$, at Sultanpur $1373.68 \mathrm{~m}^{3} / \mathrm{s}$ at Jaunpur $2991.82 \mathrm{~m}^{3} / \mathrm{s}$ and at Maighat 3521.53 $\mathrm{m}^{3} / \mathrm{s}$ but on average and $75 \%$ dependability level these flow becomes very low.

It is suggested that E-Flows assessed for Gomti river using BBM may be refined on the basis of more research carried out with informed hydrology, biodiversity habitat conditions and parameters of geomorphology.

Keywords - Environmental flows, river conservation, basin plan, water use efficiency, Building Block Methodology.

\section{INTRODUCTION}

The responses to ecological degradations are likely to be a priority for river conservation and management [Vaughan et al, 2008]. Rivers attain a stable regime over thousands of years through adjustment of slope and cross section according to the volume of water and sediment carried over time. A modification of the flow regime and obstruction in river water-way will definitely result in sediment transport dynamics and to the channel change in long run. In most of alluvial rivers like Gomti, river bed has come up about $2 \mathrm{~m}$ above 1960 bottom level, changed the slope and hence sluggishness in flow, visible by once a highly sinuous river is now turned in moderately sinuous. 


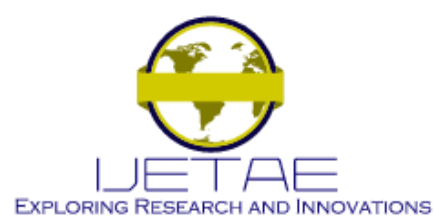

\section{International Journal of Emerging Technology and Advanced Engineering Website: www.ijetae.com (ISSN 2250-2459, ISO 9001:2008 Certified Journal, Volume 10, Issue 11, November 2020)}

Gomti river plan form dynamics is entirely changed due to low flow and no-connect to her flood plain around the city reaches.

Flows necessary for maintenance of channel form and specific morphological units based on water level could be predicted. Similarly, biological habitats and socioeconomic flow requirements could be estimated [WWFIndia, 2020]. A holistic approach- Building Block Methodology would be employed to assess environmental flows requirement of a river [Kings et al, 2008]. In general, geo-morphological requirement of flows are often higher over biological or social demands. Recommended E-flows of a river system are site specific and depend upon what people want to see their rivers should look like.

River Gomti faces floodplains encroachment in upper stretch, while the middle and lower stretches face pressure from pollution and excessive groundwater abstraction. To restore Gomti river from aquatic biodiversity perspective for which it is well known, the key concern was proliferation of invasive and hardy species in the river and their main consideration was around providing conducive hydraulic habitat for Indian Major Corps (IMCs). Fluvial geomorphology looks for lateral and longitudinal connectivity. Socio-cultural concern of people is water quality and quantity in time and space. Over all river health may be considered while recommending suitable e-flows in the river.

The Gomti river was jacketed to save the Lucknow city from flood damages by constructing embankments 250$450 \mathrm{~m}$ apart on both the banks of the river, post 1960- 1971 peak floods $\left(3564 \mathrm{~m} 3 / \mathrm{s} \& 3085 \mathrm{~m}^{3} / \mathrm{s}\right.$, respectively at Hanuman setu) and a British weir of 1911 and later in 1965 Gomti barrage was constructed to raise water level for municipal water supply at Gaughat to feed Water Works at Aishbagh (265 MLD) and Balaganj (200 MLD). The III WW at Gomtinagar (80MLD) is fed from S.S. Feeder Canal. There are 71 Minor Lift irrigation canals in Gomti Basin, having total capacity to draw 1458 cusecs (41.29 $\mathrm{m}^{3} / \mathrm{s}$ ) and CCA of 35445 ha.

Under Gomti river front development (2014-17) around the Lucknow City, the river has been engineered by controlling its width, digging bed and shaped linear to reclaim saved land by constructing RCC diaphragm wall on both the banks distancing 110 to $125 \mathrm{~m}$ apart in $16 \mathrm{~km}$ city stretch followed by parallel drains along the river on both banks to divert sewage drains and a rubber dam was constructed across the river downstream Gomti barrage near La Martinier College to raise water level for navigation around the city stretch.
Beautification, electrification, fountains, construction of road, Amphy Theater and many more plans were under the project.

In case of embankments on both banks of the river, the spacing between the embankments should not be less than 3 times Lacey wetted parameter for the design flood discharge (Q) corresponding to 100 years [GFCC, 2004] with clear waterway equal to $4.75 \mathrm{Q}^{\wedge 1 / 2}$. Lacey clear waterway for Gomti river corresponding to discharge of $3140 \mathrm{~m}^{3} / \mathrm{s}$ comes to $266 \mathrm{~m}$. River width restricted to $240 \mathrm{~m}$ and clear waterway $110-125 \mathrm{~m}$ only to reclaim land out of $450 \mathrm{~m}$ wide flood plain at places upstream of Gomti barrage. Assuming economic development will shape ecology of the river by taking pollution abatement measures and ensuring ecological flows from existing irrigation canal system off-taking from Sharda and Ghaghara rivers.

Behavior and training of Gomti river near bridges and barrages (16 in numbers in $30 \mathrm{~km}$ reach between LucknowSitapur bypass road bridge to Shaheed path) around capital city Lucknow-post river front development has been studied by the authour and found that built in cross section could take highest peak flood of $3564 \mathrm{~m}^{3} / \mathrm{s}$ at Gomti barrage and afflux created due to presence of many rail and road bridges [Ravindra, 2019]. Impact of river channelization and river front development on fluvial ecology was studied by [Dutta et al, 2018] and reported that fish habitat have been destroyed. The Gomti river water quality has been studied by many researchers [Dutta et al, 2011] and reported that barrage down stretch is most polluted as sewage of Gomtinager and waste water discharge from nearby STP is poured into the river [Alam, et al, 2020]. On the other hand, Gomti river basin plan for future water need has been prepared by TAHAL Consulting Engineers Israel/India for State Water Resources Government of Uttar Pradesh [SWARA 2020].

Recently, WWF-India in association with UPWaMReC, SWaRA and Partners have initiated assessment of environmental flows for major rivers of Uttar Pradesh [WWF-India, Oct. 2020]. These E-Flow sites are shown in Figure-1 and the location of E-F sites for Gomti river is given in Table-1.

This paper discusses the E-flows quantification and its implementation plan for Gomti river, considering the constraints of water availability in Gomti Basin and argues for flows augmentation by transferring water from Sharda and Ghaghara rivers through Lucknow branch of Sharda canal and Sharda Sahayak Feeder. 


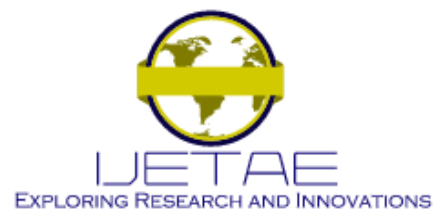

International Journal of Emerging Technology and Advanced Engineering

Website: www.ijetae.com (ISSN 2250-2459, ISO 9001:2008 Certified Journal, Volume 10, Issue 11, November 2020)

The Gomti basin setting showing canal system and related control structure on rivers is shown in Figure-1. Homozonation of basin on the basis of slope on which ground E-flows sites have been selected is shown in Figure 2.

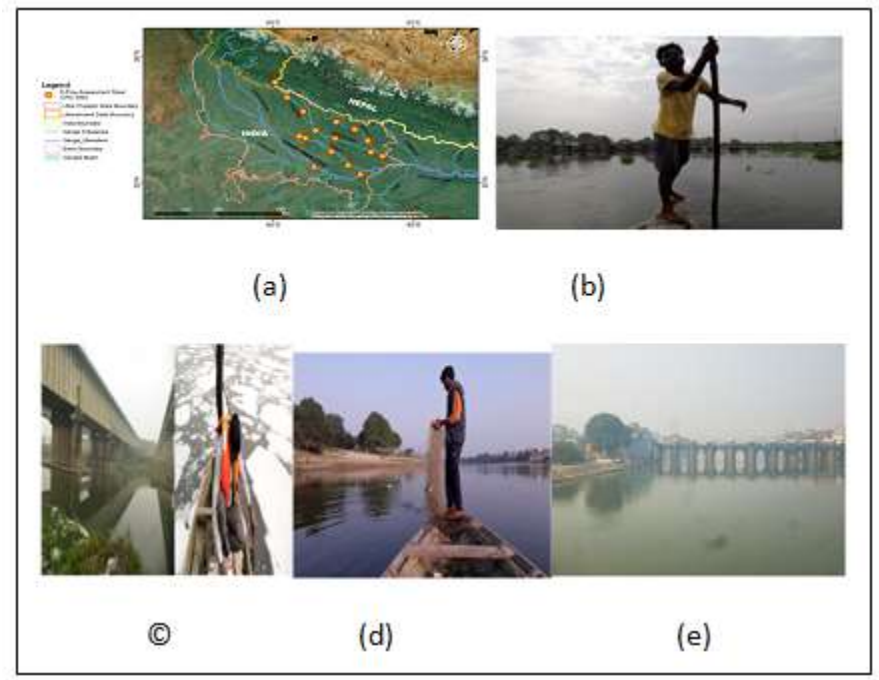

Figure-1 (A.) E-Flow Site On Major Rivers Of Uttar Pradesh, (B). Mehndighat, (C.) Aqueduct, (D.) Sultanpur, (E.) Jaunpur

Table-1

E-Flow Sites Selected On Gomti River

\begin{tabular}{|c|c|c|}
\hline Site & Location & Reason \\
\hline $\begin{array}{c}\text { Mehndi ghat, } \mathrm{u} / \mathrm{s} \\
\text { Lucknow city }\end{array}$ & $\begin{array}{c}80^{0} 56^{\prime} 47.82^{\prime \prime} \mathrm{E}, \\
26^{0} 51^{\prime} 38.599^{\prime \prime} \mathrm{N}\end{array}$ & $\begin{array}{c}\text { Abundance of aquatic } \\
\text { biodiversity, CWC } \\
\text { site }\end{array}$ \\
\hline $\begin{array}{c}\text { Indira Aqueduct, } \\
\text { Fuslauna }\end{array}$ & $\begin{array}{c}81^{0} 4^{\prime} 5.411^{\prime \prime} \mathrm{E}, 26^{0} \\
49^{\prime} 41.17^{\prime \prime} \mathrm{N}\end{array}$ & $\begin{array}{c}\text { Polluted stretch d/s } \\
\text { Gomtinagar, } \\
\text { Lucknow }\end{array}$ \\
\hline $\begin{array}{c}\text { Sultanpur, under } \\
\text { bridge }\end{array}$ & $82^{0} 4^{\prime} 27.903^{\prime \prime} \mathrm{E}$, & CWC site \\
$26^{0} 16^{\prime} 46.487^{\prime \prime} \mathrm{N}$ & \\
\hline Jaunpur, u/s Shahi & $82^{0} 39^{\prime} 50.772^{\prime \prime} \mathrm{E}$, & CWC site \\
\hline
\end{tabular}

\section{GOMTI RIVER GEOMORPHOLOGY}

A number of meander scars and ox-bow lakes $\mathrm{d} / \mathrm{s}$ of Lucknow city are drying up over the years (1991-2019). Most of older floodplain is occupied by urban settlements employing poor lateral connectivity.
Once upon a time highly sinuous (meandering length $200 \mathrm{~km}$ up to Lucknow in $490 \mathrm{~km}$ stretch), Gomti river is now moderately sinuous and does not show any plan form dynamics as has remained fixed its position for the last four decades. The mapping of channel shift and thalweg also confirms the lack of any dynamics apparently due to lack of sufficient flow. Gomti River around Lucknow lacks any sign of natural geomorphic activity due to in sufficient flow $6 \mathrm{~m} 3 / \mathrm{s}$ in May (2000-04).

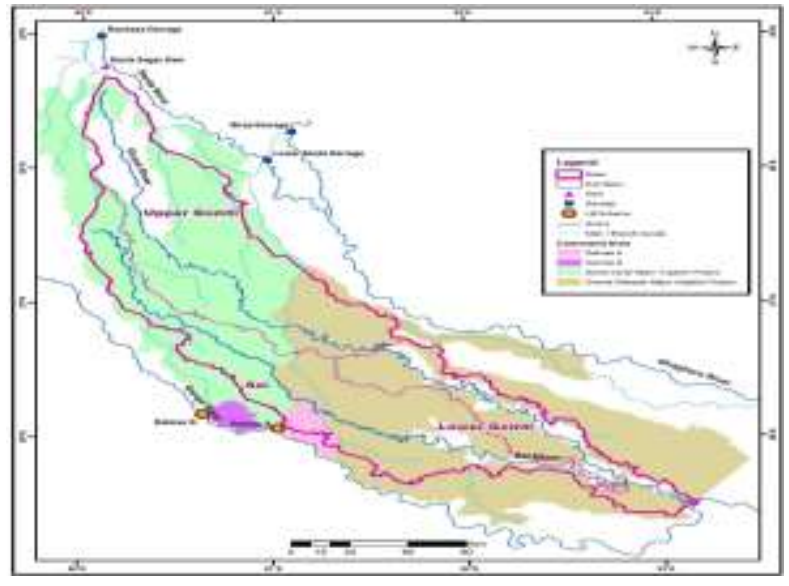

Figure 1 Canals And Related Structures On Rivers.

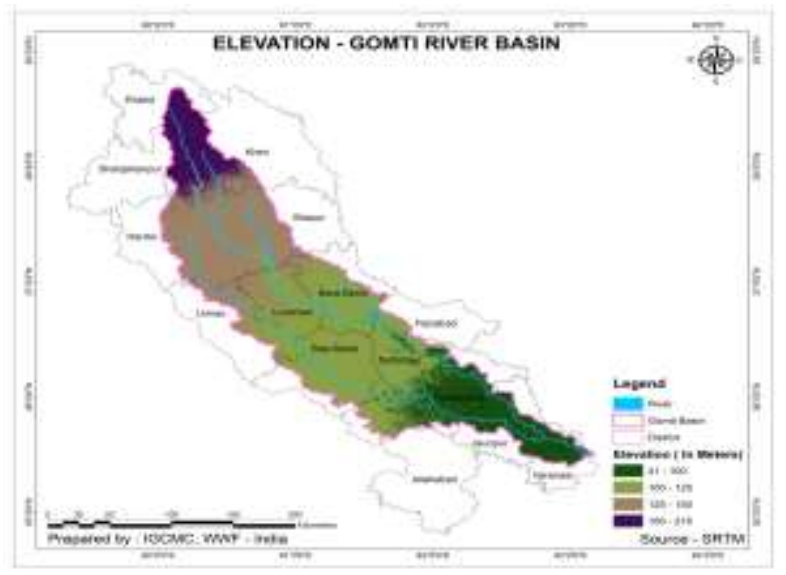

Figure 2 Elevation Map Of Gomti Basin

Sediment load at Lucknow site (1991-92 to 2013-14) is 1584 tonnes per day (0.58 million tonnes/year or 0.42 million $\mathrm{m}^{3}$ /year) for $10503 \mathrm{~km}^{2}$ i.e. 0.15 tonnes per day per $\mathrm{km}^{2}$. This corresponds to a catchment denudation rate of $0.04 \mathrm{~mm} /$ year. In low flow years the sediment load is low while the high flow years have high sediment load, maximum in the month of September. 


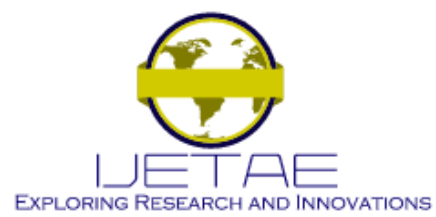

International Journal of Emerging Technology and Advanced Engineering

Website: www.ijetae.com (ISSN 2250-2459, ISO 9001:2008 Certified Journal, Volume 10, Issue 11, November 2020)

At Sultanpur most of the geomorphic features within the valley margin have being obliterated by the anthropogenic interventions, mostly in the form of agriculture and settlement. The river is characterized by very tight meanders but very few meander scars are mapped. The river has shifted $800 \mathrm{~m}$ from sinuous bend to nearly straight course. At Jaunpur the channel is symmetrical, stable and representative of single channel as Sultanpur. The cross section maximum width $949 \mathrm{~m}$ and depth $14 \mathrm{~m}$ is in main central cross section whereas downstream section is relatively shallower [Sinha, 2020].

Sediment load at Maighat site (1985-86 to 2015-16) is 6995 tonnes per day (2.55 million tonnes/year or 1.83 million $\mathrm{m}^{3} /$ year) for $30042 \mathrm{~km}^{2}$ i.e. 0.23 tonnes per day per $\mathrm{km}^{2}$. This corresponds to a catchment denudation rate of $0.06 \mathrm{~mm} /$ year. In low flow years the sediment load is low while the high flow years have high sediment load, maximum in the month of September.

\section{BIODIVERSITY SURVEY}

Alteration in the natural flow regime of the rivers have affected the habitat and the abundance of aquatic species. A total of 81 species belong to 53 genera 24 families and 7 orders were recorded in Gomti river.
Among these, 72 are native and 7 are exotic ones. Gomti river IUCN Red list data for 2000-01 is shown in Figure-3.

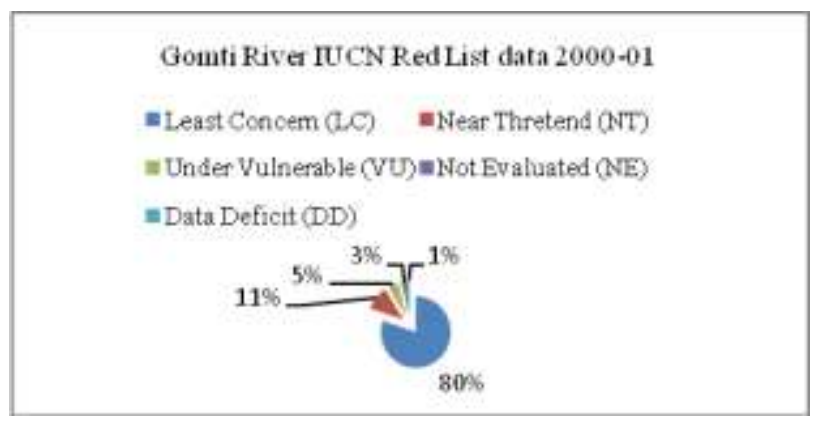

Figure-3 Biodiversity Survey For Gomti River

Source: Starter Document on biodiversity survey (WWF-India Report)

Hydrological and basic water quality observed at E-flow sites in Gomti River is given in Table-2.

\section{Socio- Cultural Perspective}

Present and desired Gomti river health category at each E-flow sites have been agreed to be degraded to moderately modified category. 


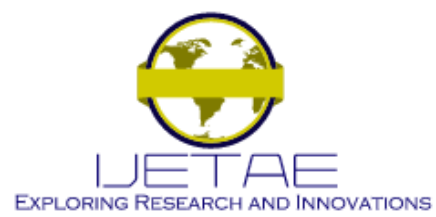

International Journal of Emerging Technology and Advanced Engineering Website: www.ijetae.com (ISSN 2250-2459, ISO 9001:2008 Certified Journal, Volume 10, Issue 11, November 2020)

\begin{tabular}{|c|c|c|c|c|c|c|c|c|}
\hline E-Flow Sites & \multicolumn{2}{|c|}{$\begin{array}{l}\text { Lucknow-Mehndighat } \\
\text { US Hanuman Setu }\end{array}$} & \multicolumn{2}{|c|}{ Lucknow Aqueduct } & \multicolumn{2}{|c|}{ Sultanpur under bridge } & \multicolumn{2}{|c|}{ Jaurpur u/s Shahi pul } \\
\hline $\begin{array}{c}\text { River } \\
\text { depth'width } \\
\text { in m }\end{array}$ & Surrumer & Monsoon & Surnmer & Monsoon & Surnumer & Monsoon & Surnuruer & Monsoon \\
\hline $\begin{array}{l}\text { Av. depth } \\
\text { (Mir, Max) }\end{array}$ & $\begin{array}{c}2.15 \\
(0.76-3.35)\end{array}$ & $\begin{array}{c}1.14 \\
(0.76-2.62)\end{array}$ & \multirow{3}{*}{$\begin{array}{c}\text { Survey } \\
\text { not } \\
\text { conducted } \\
\text { as site was } \\
\text { decided } \\
\text { later }\end{array}$} & $\begin{array}{c}4.33 \\
(2.5-5.9)\end{array}$ & \multirow{3}{*}{$\begin{array}{c}\text { Survey } \\
\text { not } \\
\text { conducted } \\
\text { as site was } \\
\text { decided } \\
\text { later }\end{array}$} & $\begin{array}{c}4.54 \\
(2.5-8.0)\end{array}$ & $\begin{array}{c}4.84 \\
(3.7-6.10)\end{array}$ & $\begin{array}{c}5.96 \\
(2.7-8.2)\end{array}$ \\
\hline River width & 80 & 90 & & 100 & & 50 & 50 & 50 \\
\hline $\begin{array}{l}\text { Average flow } \\
\text { Velocity } \\
\text { (misec) }\end{array}$ & 0.100 & 0.060 & & 0.08 & & 0.47 & 0.133 & 0.070 \\
\hline \multicolumn{9}{|c|}{ Water Quality basic parameters } \\
\hline Colour & Clear & Greenish & \multirow{5}{*}{$\begin{array}{c}\text { Survey } \\
\text { not } \\
\text { conducted } \\
\text { as site was } \\
\text { decided } \\
\text { later }\end{array}$} & Black & \multirow{5}{*}{$\begin{array}{c}\text { Survey } \\
\text { not } \\
\text { conducted } \\
\text { as site was } \\
\text { decided } \\
\text { later }\end{array}$} & Black & Greerish & Greenish \\
\hline $\mathrm{pH}$ & 8.9 & 9.2 & & 8.2 & & 9.4 & 8.3 & 9.4 \\
\hline Temp $\left({ }^{\circ} \mathrm{C}\right)$ & 32.4 & 22.6 & & 23.5 & & 23.1 & 35 & 23.1 \\
\hline $\mathrm{DO}(\mathrm{mg} /)$ & 7.5 & 7 & & 4 & & 3.8 & 6.8 & 7 \\
\hline TDS (mg/) & 195 & 225 & & 405 & & 361 & 240 & 361 \\
\hline
\end{tabular}

Water quality and quantity are the main concern of bank's community. Imperial gazetteers inform that in ancient period Gomti was a dynamic sinuous and biodiversity rich river with sluggish flow. River width in upper stretch was limited to $100-200 \mathrm{~m}$, in middle around Lucknow 200-400 $\mathrm{m}$ and in lower stretches 400-600 m. Today flood plains are encroached for settlement and agricultural use. Dense Namish Aranya (forests) are lean and Shiva temples dotted all along its bank. Oozing groundwater is seen in some of religious places along Gomti River.

\section{E-Flows Motivation Methodology}

Two target conditions are considered, one for normal maintenance year which is neither wet nor dry hydraulic year, and second is for drought year. Flushing needs of higher order discharge for two weeks is also taken into account. The river health category targeted is from degraded to moderately modified. The flow motivations for different thematic groups are listed in Table 3. 


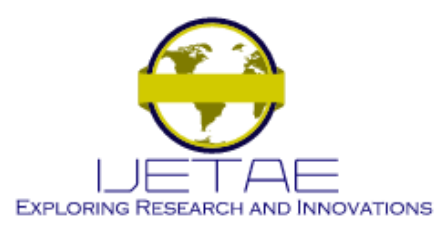

International Journal of Emerging Technology and Advanced Engineering Website: www.ijetae.com (ISSN 2250-2459, ISO 9001:2008 Certified Journal, Volume 10, Issue 11, November 2020)

\begin{tabular}{|c|c|c|}
\hline \multicolumn{3}{|c|}{ TABLE-3 E-FLOWS MOTIVATION METHODOLOGY } \\
\hline Thematic Group & Motivation for Normal Maintenance & Motivation for Drought year \\
\hline Biodiversity & $\begin{array}{l}\text { The size and weight of fish are significantly } \\
\text { affected by lower depth. In summer (dry season) } \\
\text { to maintain congenial thermal profile for the } \\
\text { fish, to maintain desired DO; The recommended } \\
\text { wet season depth is suitable for Temperature } \\
\text { variation, Oxygen, plankton production etc. }\end{array}$ & $\begin{array}{l}\text { Minimum required water depth to maintain } \\
\text { fish base around the site. The recommended } \\
\text { wet season minimum water depth to have } \\
\text { pool connectivity, which are useful for } \\
\text { nutrient flow and growth of food chain. }\end{array}$ \\
\hline Geomorphology & $\begin{array}{l}\text { The aim is to maintain lateral and longitudinal } \\
\text { connectivity in the river during dry and wet } \\
\text { seasons and would sustain some geomorphic } \\
\text { activity in the form of sediment disposal. } \\
\text { Additional requirement of flow to completely } \\
\text { inundate the channel belt and some portion of } \\
\text { floodplain for two weeks duration. }\end{array}$ & $\begin{array}{l}\text { Minimum water depth to maintain } \\
\text { longitudinal connectivity and partial lateral } \\
\text { connectivity. }\end{array}$ \\
\hline Socio-cultural & $\begin{array}{l}\text { The recommended water depth is corresponding } \\
\text { to people memories of historic flows, and this } \\
\text { will also improve the soil moisture and fishing } \\
\text { based livelihoods. }\end{array}$ & $\begin{array}{l}\text { Present day flow acceptable to perform } \\
\text { rituals and livelihood activity carried out } \\
\text { though with difficulty.. }\end{array}$ \\
\hline
\end{tabular}

VI. E-Flow Estimation PROCESSES

\section{1. $L U C K N O W$}

TABLE-4

E-FLOWS RECOMMENDED FOR MEHNDIGHAT SITE U/S LUCKNOW CITY, GOMTI RIVER

\begin{tabular}{|c|c|c|c|c|c|c|}
\hline e-flows & \multicolumn{2}{|c|}{ Normal Maintenance Year } & \multicolumn{3}{c|}{ Drought year } \\
\cline { 2 - 7 } & $\begin{array}{c}\text { Leanest } \\
\text { month } \\
\text { Jan. }\end{array}$ & $\begin{array}{c}\text { Wet } \\
\text { month, } \\
\text { Aug. }\end{array}$ & $\begin{array}{c}\text { Flushin } \\
\text { g in } \\
\text { wettest } \\
\text { (Sep) }\end{array}$ & $\begin{array}{c}\text { Dries } \\
\mathrm{t} \\
\text { mont } \\
\mathrm{h}\end{array}$ & $\begin{array}{c}\text { Wet } \\
\text { month, } \\
\text { Aug }\end{array}$ & $\begin{array}{c}\text { Flushin } \\
\text { g in } \\
\text { wettest } \\
\text { (Sep) }\end{array}$ \\
\hline $\begin{array}{c}\text { Water } \\
\text { level in } \\
\text { m, }\end{array}$ & $\begin{array}{c}\text { RL(105.6 } \\
5)\end{array}$ & $\begin{array}{c}5.5 \mathrm{RL} \\
(107.6 \\
5)\end{array}$ & $\begin{array}{c}6.0 \\
\mathrm{RL}(10 \\
8.15)\end{array}$ & $\begin{array}{c}2.5 \\
\mathrm{RL} \\
(104 .\end{array}$ & $\begin{array}{c}5 \mathrm{RL} \\
(107.15)\end{array}$ & $\begin{array}{c}5.5 \\
(107.6 \\
5)\end{array}$ \\
\hline $\begin{array}{c}\text { Discharg } \\
\text { e in m3/s }\end{array}$ & 183.72 & 415 & 600 & 129 & 406 & 415 \\
\hline
\end{tabular}

(i). For Mehndighat site, the water depths and corresponding likely flows recommended has been given in Table-4. On the cross section various water depth requirements for normal maintenance and dry year is shown in Figure 4.

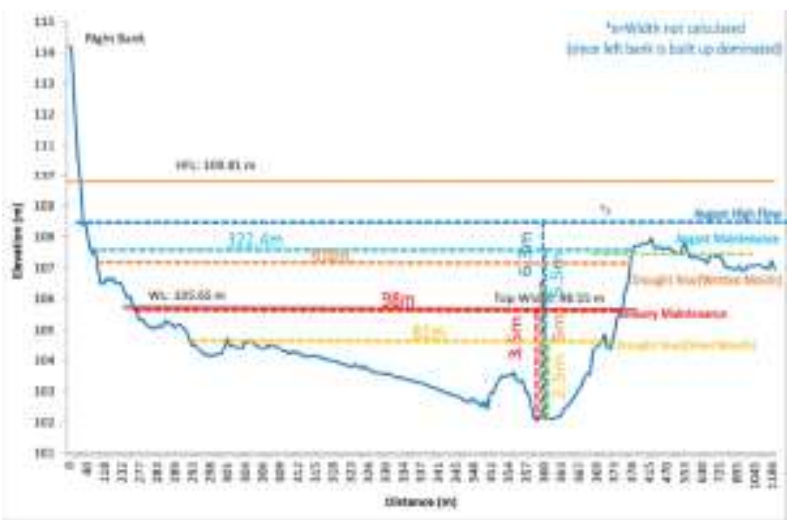

Figure 4. Recommended E-Flow For Mehndighat, U/S Lucknow Barrage 


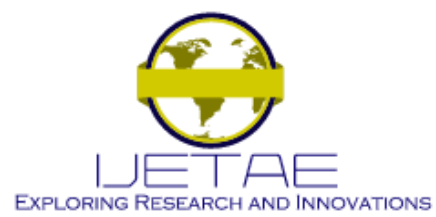

International Journal of Emerging Technology and Advanced Engineering Website: www.ijetae.com (ISSN 2250-2459, ISO 9001:2008 Certified Journal, Volume 10, Issue 11, November 2020)

\begin{tabular}{|c|c|c|c|c|c|c|c|c|c|c|c|c|c|}
\hline $\begin{array}{l}\text { Flow } \\
\text { Volume* in } \\
\text { MCM }\end{array}$ & Jan & Feb & Mar & Apr & May & Jun & Jul & Aug & Sep & Oct & Nov & Dec & Annual \\
\hline Virgin & 95.86 & 58.38 & 34.00 & 20.40 & 14.81 & 62.94 & 544.54 & 856.07 & 805.93 & 489.58 & 251.04 & 152.55 & 3386.10 \\
\hline Observed & 85.63 & 68.46 & 72.08 & 62.23 & 59.30 & 71.95 & 171.61 & 312.89 & 465.63 & 282.81 & 123.79 & 102.93 & 1879.31 \\
\hline E-Flows & 492.37 & 352.30 & 415.02 & 340.64 & 338.80 & 396.08 & 516.65 & 1112.2 & 1554 & 847.01 & 356.48 & 304.93 & 7026.48 \\
\hline
\end{tabular}

For Gomti river at Lucknow Average monthly virgin, observed and recommended E-Flows is given in Table-5 and shown in Figure 5. It is found that average annual virgin flow volume (1961-2015) is 3386.10 MCM, observed average annual flow volume (1985-2015) is 1879.31MCM whereas recommended annual E-flows volume is $7026.48 \mathrm{MCM}$ for Mehndighat. Recommended monthly E-flows for Mehndighat is higher than the observed flows and even more than virgin flow volume except in the month of July. Hence WWF-India E-flows recommendation for Mehndighat is not acceptable.

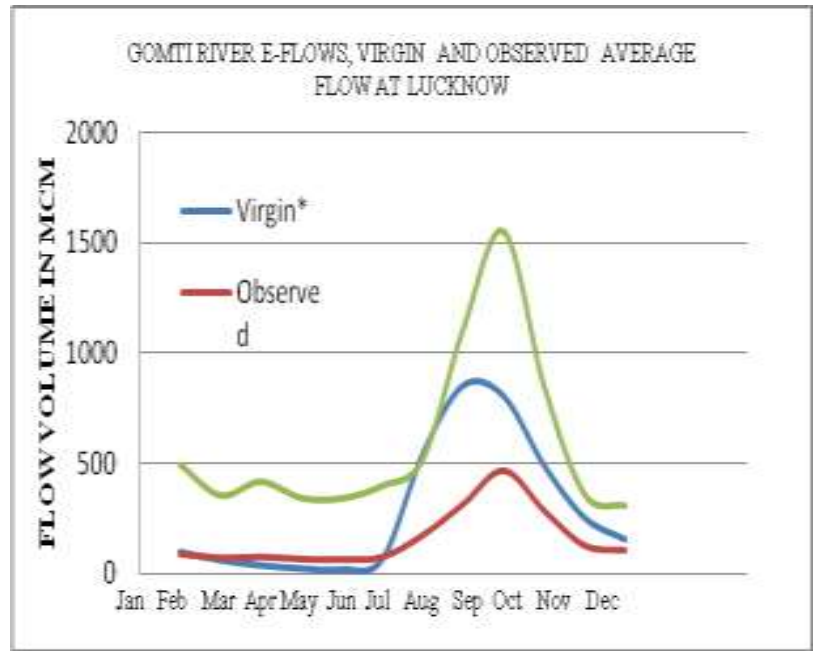

Figure 5: Average Monthly Virgin, Observed And Suggested E-Flows For Gomti River At Mehndighat, Lucknow
Table-6

E-Flows Recommended For Fuslauna E-F Site, Aqueduct D/S Gomtinagar, Lucknow

\begin{tabular}{|c|c|c|c|c|c|c|}
\hline \multirow[t]{2}{*}{ E-flows } & \multicolumn{3}{|c|}{ Normal Maintenance Year } & \multicolumn{3}{|c|}{ Drought year } \\
\hline & $\begin{array}{c}\text { Leanest } \\
\text { month } \\
\text { Jan. }\end{array}$ & $\begin{array}{c}\text { Wet } \\
\text { mont } \\
\text { h, } \\
\text { Aug. }\end{array}$ & $\begin{array}{c}\text { Flushing } \\
\text { in } \\
\text { wettest } \\
\text { Sep }\end{array}$ & $\begin{array}{c}\text { Driest } \\
\text { month } \\
\text { Jan. }\end{array}$ & $\begin{array}{c}\text { Wet } \\
\text { mont } \\
\text { h, } \\
\text { Aug }\end{array}$ & $\begin{array}{c}\text { Flushi } \\
\text { ng in } \\
\text { wettest } \\
\text {, Sep. }\end{array}$ \\
\hline $\begin{array}{c}\text { Water } \\
\text { level in } \\
\mathrm{m},\end{array}$ & $\begin{array}{c}3 \\
\text { RL(101. } \\
5)\end{array}$ & $\begin{array}{c}5.3 \\
\text { RL } \\
(103 . \\
8)\end{array}$ & $\begin{array}{c}6 \\
\text { RL(104. } \\
5)\end{array}$ & $\begin{array}{c}2.25 \\
\mathrm{RL} \\
100.7 \\
5)\end{array}$ & $\begin{array}{c}3.5 \\
\text { RL } \\
(102)\end{array}$ & $\begin{array}{c}5 \\
(103.5)\end{array}$ \\
\hline $\begin{array}{c}\text { Dischar } \\
\text { ge in } \\
\mathrm{m} 3 / \mathrm{s}\end{array}$ & 58 & 111 & 170 & 29 & 42 & 65 \\
\hline
\end{tabular}

On the cross section various water depth requirements for normal maintenance and drought year is shown in Figure 6.

E-flows hydrograph for maintenance year and drought year has been plotted and shown in Figure 7 and Figure 8.

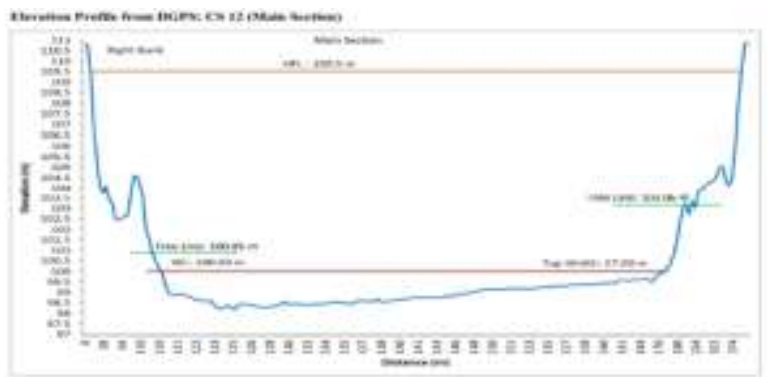

Figure 6 Gomti River Cross Section At Fuslauna, Downstream Indira Aqueduct, Gomtinagar, Lucknow 


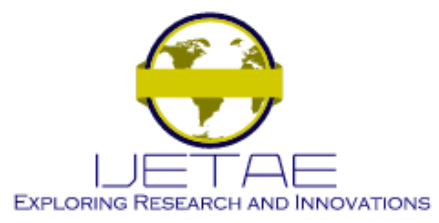

International Journal of Emerging Technology and Advanced Engineering Website: www.ijetae.com (ISSN 2250-2459, ISO 9001:2008 Certified Journal, Volume 10, Issue 11, November 2020)

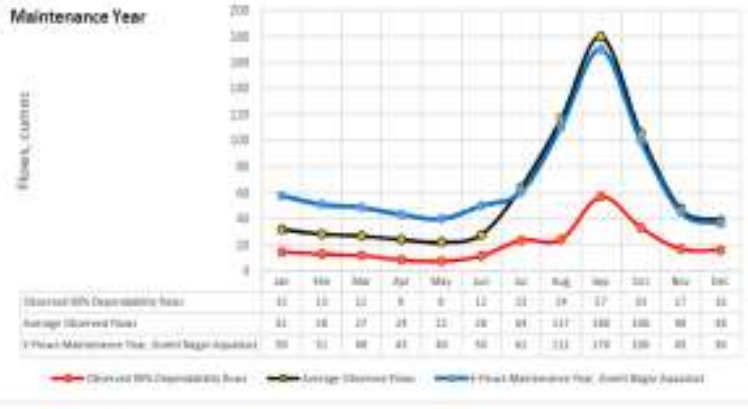

Figure 7 Recommended E-Flows In Gomti River At Aqueduct Site For Maintenance Year

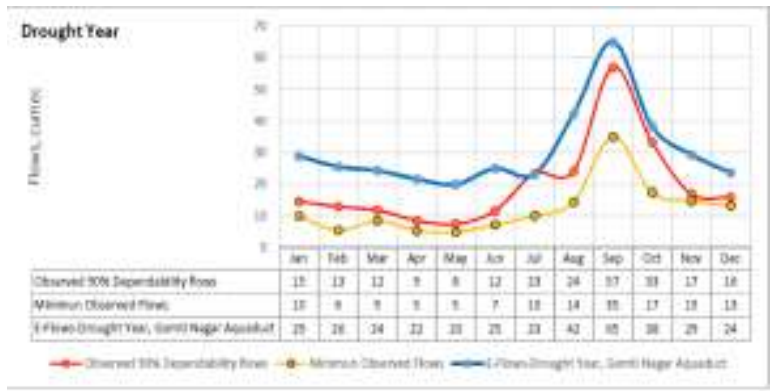

Figure 8 Recommended E-Flows In Gomti River At Aqueduct Site For Drought Year

It is found from Figure 7 that recommended E-Flows are almost double of the average observed flows in Gomti river at Gomtinagar. Perusal of Figure 8 shows that recommended e-flows for drought year is not available in the Gomti river, as minimum observed flows are almost half of required E-flows. Augmentation of minimum flows in Gomti river d/s Lucknow during $15^{\text {th }}$ Feb to $15^{\text {th }}$ June from Sharda Sahayak Feeder Canal through Gomti escape to outfall upstream of Indira Aqueduct is recommended through Gomti escape of S.S.Feeder.

To check that whether e-flows are within the limits of virgin flow at Indira Aqueduct or not, figure 9 has been plotted. In this figure virgin flow corresponding to Upper Gomti Basin estimate and observed flow corresponding to CWC Hanuman Setu has been considered without any modification rather assuming the same.

Perusal of Figure 9 informs that recommended e-flows are higher than estimated virgin and observed flow for the months of Jan to June and for rest of the months July to Dec, e-flows values are within virgin/observed flow volume limits.

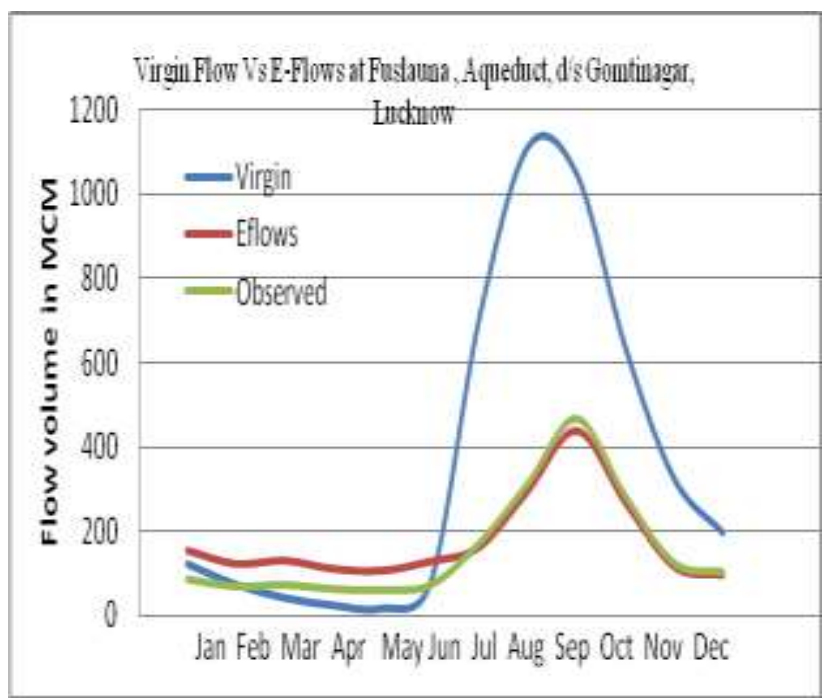

Figure 9 Virgin Flow Vs E-Flows At Fuslauna , Aqueduct, D/S Gomtinagar, Lucknow

\section{SULTANPUR E-F SITE}

For Sultanpur site, the water depths and corresponding likely flows recommended has been given in Table -7 .

On the cross section various water depth requirements for normal maintenance and drought year is shown in Figure 10.

Table-7

E-Flows Recommended For Sultanpur

\begin{tabular}{|c|c|c|c|c|c|c|}
\hline \multirow[t]{2}{*}{ E-flows } & \multicolumn{3}{|c|}{ Normal Maintenance Year } & \multicolumn{3}{|c|}{ Drought year } \\
\hline & $\begin{array}{c}\text { Leanest } \\
\text { month } \\
\text { Jan. }\end{array}$ & $\begin{array}{c}\text { Wet } \\
\text { mont } \\
\text { h, } \\
\text { Aug. }\end{array}$ & $\begin{array}{c}\text { Flushin } \\
\mathrm{g} \text { in } \\
\text { wettest } \\
\text { Sep }\end{array}$ & $\begin{array}{c}\text { Dries } \\
\mathrm{t} \\
\text { mont } \\
\mathrm{h} \\
\text { Jan. }\end{array}$ & $\begin{array}{c}\text { Wet } \\
\text { mont } \\
\text { h, } \\
\text { Aug }\end{array}$ & $\begin{array}{c}\text { Flushin } \\
\mathrm{g} \text { in } \\
\text { wettest, } \\
\text { Sep. }\end{array}$ \\
\hline $\begin{array}{c}\text { Water } \\
\text { level in } \\
\mathrm{m},\end{array}$ & $\begin{array}{c}2.25 \\
\mathrm{RL}(80.7 \\
5)\end{array}$ & $\begin{array}{c}7.5 \\
\mathrm{RL} \\
(86.0 \\
)\end{array}$ & $\begin{array}{c}9 \\
\text { RL(87. } \\
5)\end{array}$ & $\begin{array}{c}2 \mathrm{RL} \\
(80.5 \\
)\end{array}$ & $\begin{array}{c}3.5 \\
\text { RL } \\
(81.5)\end{array}$ & $5(83.5)$ \\
\hline $\begin{array}{l}\text { Discharg } \\
\text { e in } \mathrm{m} 3 / \mathrm{s}\end{array}$ & 137 & 618 & 950 & 90 & 150 & 230 \\
\hline
\end{tabular}




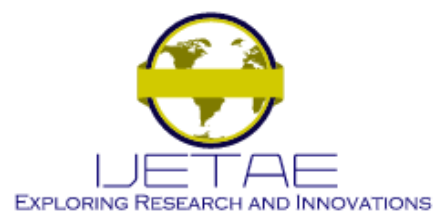

International Journal of Emerging Technology and Advanced Engineering Website: www.ijetae.com (ISSN 2250-2459, ISO 9001:2008 Certified Journal, Volume 10, Issue 11, November 2020)

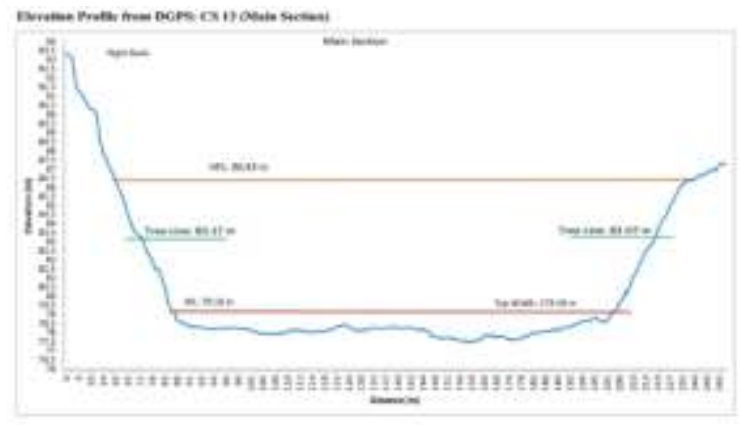

Figure 10 Gomti River Cross Section At Sultanpur

E-flows hydrograph for maintenance year and drought year has been plotted and shown in Figure 11 and Figure 12.

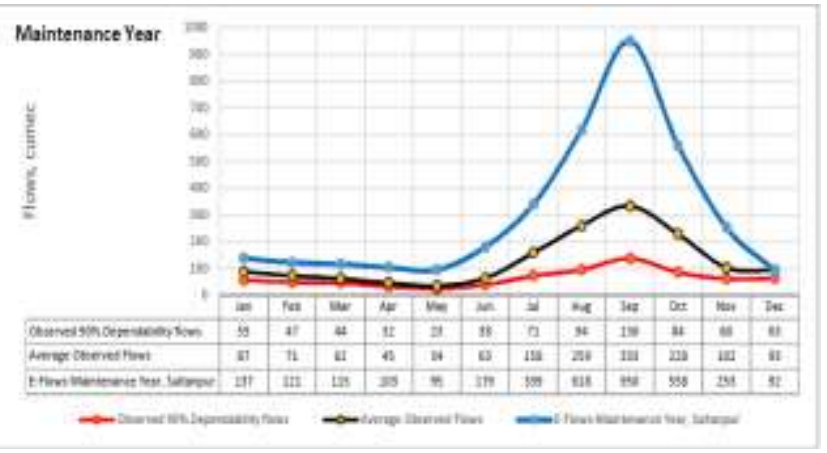

Figure 11 Recommended E-Flows In Gomti River At Sultanpur Site For Maintenance Year

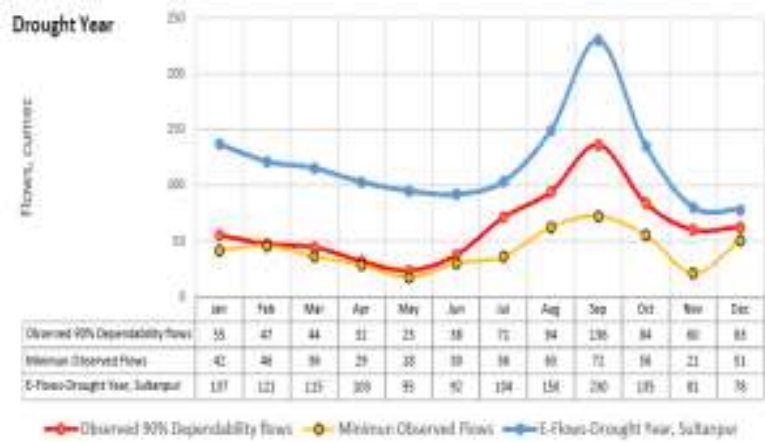

Figure 12 Recommended E-Flows In Gomti River At Sultanpur Site For Drought Year

Perusal of Figure 11 and Figure 12 suggest that recommended EF values are far higher than the observed flows at Sultanpur.
3. JAUNPUR E-F SITE U/S SHAHI PUL

For Jaunpur site, the water depths and corresponding likely flows recommended has been given in Table -8 .

Table- 8

E-Flows Recommended For Jaunpur

\begin{tabular}{|c|c|c|c|c|c|c|}
\hline \multirow[t]{2}{*}{ E-flows } & \multicolumn{3}{|c|}{$\begin{array}{c}\text { Normal Maintenance } \\
\text { Year }\end{array}$} & \multicolumn{3}{|c|}{ Drought year } \\
\hline & $\begin{array}{c}\text { Leane } \\
\text { st } \\
\text { month } \\
\text { Jan. }\end{array}$ & $\begin{array}{c}\text { Wet } \\
\text { mont } \\
\text { h, } \\
\text { Aug. }\end{array}$ & $\begin{array}{c}\text { Flushi } \\
\text { ng in } \\
\text { wettest } \\
\text { Sep }\end{array}$ & $\begin{array}{c}\text { Dries } \\
\mathrm{t} \\
\text { mont } \\
\mathrm{h} \\
\text { Jan. }\end{array}$ & $\begin{array}{c}\text { Wet } \\
\text { mont } \\
\mathrm{h}, \\
\text { Aug }\end{array}$ & $\begin{array}{c}\text { Flushi } \\
\text { ng in } \\
\text { wettest } \\
\text {, Sep. }\end{array}$ \\
\hline $\begin{array}{c}\text { Water } \\
\text { level in } \\
m,\end{array}$ & $\begin{array}{c}3 \\
\text { RL(69 } \\
)\end{array}$ & $\begin{array}{l}7 \mathrm{RL} \\
(73)\end{array}$ & $\begin{array}{c}11 \\
\operatorname{RL}(77)\end{array}$ & $\begin{array}{c}2 \mathrm{RL} \\
(68)\end{array}$ & $\begin{array}{c}3.6 \\
\text { RL } \\
(69.6 \\
)\end{array}$ & $5(71)$ \\
\hline $\begin{array}{c}\text { Dischar } \\
\text { ge in } \\
\text { m3/s }\end{array}$ & 144 & 517 & 795 & 108 & 137 & 210 \\
\hline
\end{tabular}

On the cross section various water depth requirements for normal maintenance and drought year is shown in Figure 13.

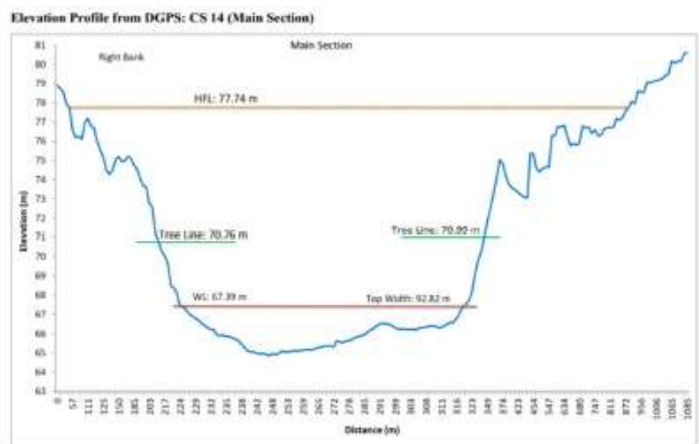

Figure 13 Gomti River Cross Section At Jaunpur

E-flows hydrograph for maintenance year and drought year has been plotted and shown in Figure 14 and Figure 15. 


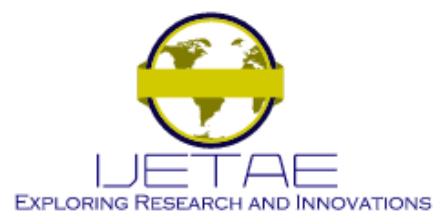

International Journal of Emerging Technology and Advanced Engineering Website: www.ijetae.com (ISSN 2250-2459, ISO 9001:2008 Certified Journal, Volume 10, Issue 11, November 2020)

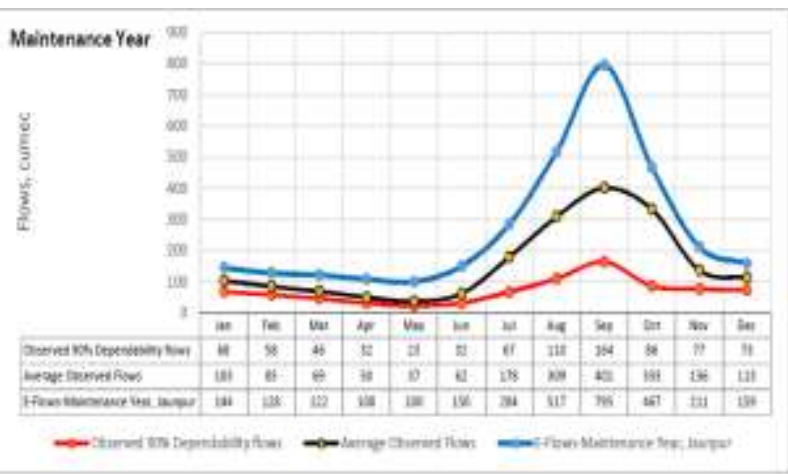

Figure 14 Recommended E-Flows In Gomti River At Jaunpur Site For Maintenance Year

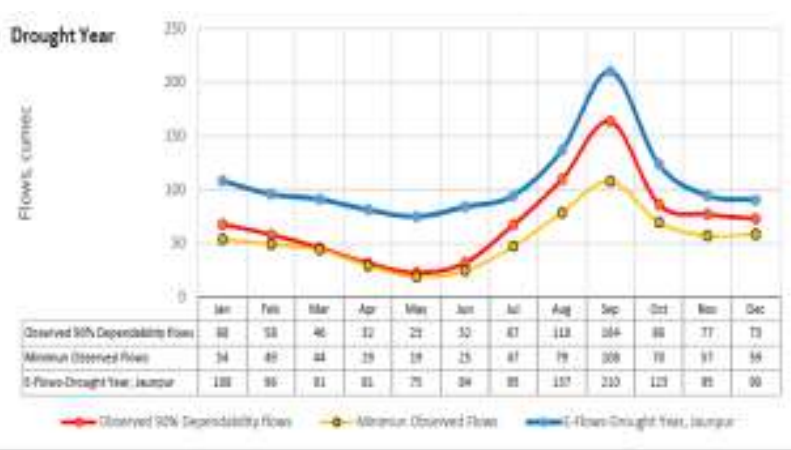

Figure 15 Recommended E-Flows In Gomti River At Jaunpur Site For Drought Year

It is found that required e-flows are almost double higher than the present day flows in Gomti river at Jaunpur. To check the e-flows value whether they are within virgin flow limits or not, let us consider the virgin flow at Maighat which is CWC gauge site d/s Jaunpur. The virgin flow is estimated at Maighat based on 1961-2015 rainfall data series.
Average annual virgin flow volume at Gomti Basin end is 9889.34 MCM. Hydrograph is shown in Figure 16 and discharge is given in Table 9.

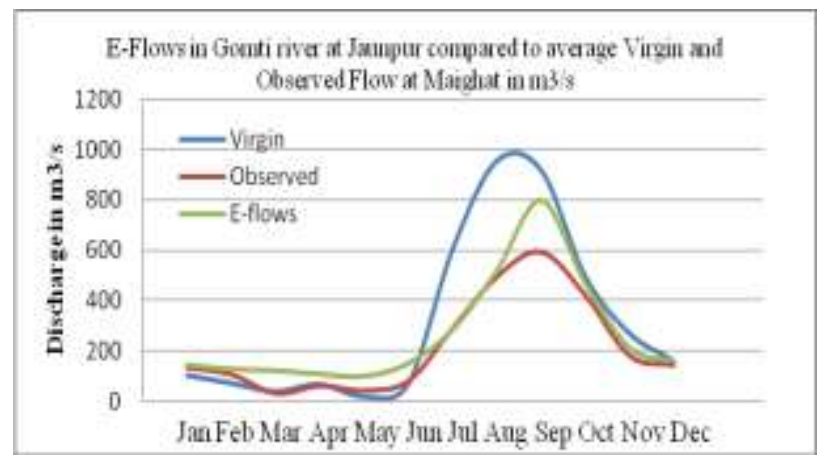

Figure 16. Virgine, Observed And E-Flows For Gomti River At Maighat, Jaunpur (In M3/S)

It is evident from Figure 16 that recommended E-flows values for Gomti river at Jaunpur is higher than the virgin flow for the month of January to June, hence unprticable. Augmentation of flows in Gomti river is recommended by increasing base flows contribution particularly during lean flow months.

\section{E-Flows EstiMATION CONSIDERING HYDRAULIC PERSPECTIVES}

Alternatively, low order e-flows based on MOWR guidelines considering hydraulic perspective only for Gomti river at Lucknow, Sultanpur, Jaunpur and Maighat is calculated based on 1985-2015 CWC flow data on 75\% dependability and given in Table-10. E-flow estimates for Lucknow comes to $15.02 \mathrm{~m}^{3} / \mathrm{s}, 7.70 \mathrm{~m}^{3} / \mathrm{s}$ and $3.41 \mathrm{~m}^{3} / \mathrm{s}$ during monsoon (June to Sep.), non lean flow month (Oct $\&$ Nov.) and lean flow months Dec to May respectively.

TABLE-9.

AVERAGE MONTHLY VIRGIN, OBSERVED AND E-FLOWS IN M3/S FOR GOMTI RIVER AT MAIGHAT, JAUNPUR D/S EF SITE

\begin{tabular}{|c|c|c|c|c|c|c|c|c|c|c|c|c|}
\hline $\begin{array}{c}\text { Flows in } \\
\text { m3/s }\end{array}$ & Jan & Feb & Mar & Apr & May & Jun & Jul & Aug & Sep & Oct & Nov & Dec \\
\hline Virgin & 103.38 & 72.43 & 39.88 & 67.80 & 18.65 & 70.72 & 605.20 & 957.00 & 919.69 & 496.87 & 269.51 & 160.74 \\
\hline Observed & 134.81 & 107.72 & 33.18 & 63.11 & 44.19 & 81.39 & 290.73 & 493.5 & 592.35 & 420.16 & 181.83 & 144.22 \\
\hline E-flows & 144 & 128 & 122 & 108 & 100 & 150 & 284 & 517 & 796 & 467 & 211 & 159 \\
\hline
\end{tabular}




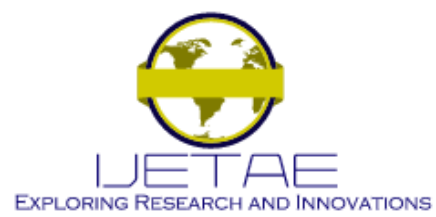

International Journal of Emerging Technology and Advanced Engineering Website: www.ijetae.com (ISSN 2250-2459, ISO 9001:2008 Certified Journal, Volume 10, Issue 11, November 2020)

Table 10

E-Flows Estimates For Gomti River At Lucknow, Sultanpur,Jaunpur And Maighat Considering Hydrological Perspective Only

\begin{tabular}{|l|l|l|l|}
\hline & $\begin{array}{l}\text { @30\% of } \\
\text { Monsoon } \\
\text { month } \\
\text { Requirement } \\
\text { average } \\
\text { flow }\end{array}$ & $\begin{array}{l}\text { @25\% of } \\
\text { Oct. \& } \\
\text { Nov }\end{array}$ & $\begin{array}{l}\text { @20\% of } \\
\text { average } \\
\text { discharge for } \\
\text { lean flow } \\
\text { months }\end{array}$ \\
\hline Lucknow & 15.02 & 7.70 & 3.41 \\
\hline Sultanpur & 42.70 & 23.73 & 10.26 \\
\hline Jaunpur & 44.94 & 29.22 & 11.28 \\
\hline Maighat & 78.09 & 40.01 & 13.92 \\
\hline
\end{tabular}

Perusal of Table-10 and Table 11 suggests that E-Flows estimate using Hydrological perspective gives a very conservative figure whereas consideration of biodiversity and geo-morphological perspective using BBM shows higher value of flows (refer column 5 in Table 11.) The reason of this great difference is that one is based on average regulated flows whereas the second mimics the natural (virgin) flow of the river, indicating that E-flows should not be estimated by hydrological consideration. It will not solve the ecological degradation and loss of goods and services provided by a river. Now the question is where from E-flows may be implemented. For this water resources availability is estimated and allocation of e-flows has been assessed.
TABLE 11 E-FLOWS ASSESSMENT FOR GOMTI RIVER AT LUCKNOW, SULTANPUR, JAUNPUR USING BBM

\begin{tabular}{|c|c|c|c|c|c|}
\hline \multirow[t]{2}{*}{ EF sites } & \multicolumn{3}{|c|}{$\begin{array}{l}\text { Target Normal Maintenance } \\
\text { Year }\end{array}$} & \multirow{2}{*}{$\begin{array}{l}\text { Average } \\
\text { Monthly } \\
\text { discharge } \\
\text { range }\end{array}$} & \multirow{2}{*}{$\begin{array}{l}\text { Duration of } \\
\text { not } \\
\text { fulfillment of } \\
\text { EF as } \\
\text { compared to } \\
\text { observed } \\
\text { hydrology }\end{array}$} \\
\hline & water dep & in $m$ & $\begin{array}{l}\text { Flushing } \\
\text { for } 15 \text { days } \\
\text { in } \mathrm{m}\end{array}$ & & \\
\hline 1 & 2 & 3 & 4 & 5 & 6 \\
\hline $\begin{array}{l}\text { Gomti } \\
\text { River }\end{array}$ & $\begin{array}{l}\text { Summer } \\
\text { season }\end{array}$ & $\begin{array}{l}\text { Wet } \\
\text { season }\end{array}$ & $/(\mathrm{m} 3 / \mathrm{s})$ & $\mathrm{m} 3 / \mathrm{s}$ & Refer graphs \\
\hline $\begin{array}{l}\text { Mehndigha } \\
\text { t Lucknow } \\
\text { u/s Barrage }\end{array}$ & 3.5 & 5.5 & $6.3(600)$ & $184-415$ & $\begin{array}{l}\text { Jan to May } \\
\text { (5 months) }\end{array}$ \\
\hline $\begin{array}{l}\text { Indira } \\
\text { Aqueduct, } \\
\text { Lucknow } \\
\text { d/s } \\
\text { Gomtinagar }\end{array}$ & 3 & 5.3 & $6.8(310)$ & $40-58$ & $\begin{array}{l}\text { Ian to Jun } \\
\text { (6 months) }\end{array}$ \\
\hline Sultanpur & 2.25 & 7.5 & 9 (1370) & $92-950$ & $\begin{array}{l}\text { Jan to Dec } \\
\text { (12 months) }\end{array}$ \\
\hline Jaunpur & 3 & 7 & $11(2450)$ & $100-795$ & $\begin{array}{l}\text { Jan to Dec } \\
\text { (12 months) }\end{array}$ \\
\hline
\end{tabular}




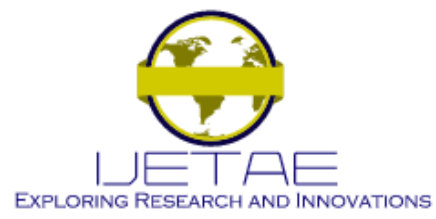

International Journal of Emerging Technology and Advanced Engineering

Website: www.ijetae.com (ISSN 2250-2459, ISO 9001:2008 Certified Journal, Volume 10, Issue 11, November 2020)

\section{AVAILABLE WATER RESOURCES IN GOMTI BASIN}

\section{(i). RAINWATER}

Rainfall average(1961-2015) is 872.67 MCM and trend analysis shows no appreciable change in Gomti basin. Monthly average annual rainfall water on basin area of $31433.67 \mathrm{~km} 2$ is $27431.2 \mathrm{MCM}$ with monsoon availability of $25022.8 \mathrm{MCM}(796.1 \mathrm{~mm})$ and non-monsoon availability of 2408.4 MCM (76.6 mm).

\section{Virgin Flow Volume}

Virgin flow volume series has been generated for Gomti Basin and its sub basins from 1961 to 2015 rainfall data. The annual virgin flow volume for Upper Gomti sub basin $\left(13586.12 \mathrm{~km}^{2}\right)$, Sai Sub basin(12188.39 $\mathrm{km}^{2}$ ), lower Gomti sub basin $\left(5659.16 \mathrm{~km}^{2}\right)$ is estimated at 4397.53 MCM, 3423.01 MCM, 2068.74 MCM and 9889.29 MCM respectively.

\section{(ii) Dynamic Groundwater Resource}

Using Groundwater Estimation Methodology of 2015, dynamic annual replenish able groundwater resource in the Gomti basin has been estimated as 10,283.00 MCM and annual groundwater draft as on $3 / 2015$ is $9512.00 \mathrm{MCM}$ giving stage of groundwater extraction $92.50 \%$, i.e. in critical category.

\section{Total Water Resources available in Gomti Basin}

Some of local surface water (generated within basin due to rainfall runoff), imported canal water from Banbasa barrage through Sharda Canal system and from Lower Sharda barrage (including inflow from Girja barrage on Ghaghara river) and dynamic groundwater resource comes to $35210.34 \mathrm{MCM}$ at $90 \%$ dependability as given in Table 12

\section{Utilizable Water Resources in Gomti Basin}

a) Generated within Gomti basin: At outfall of Gomti basin, availability of observed flow in Gomti river at $75 \%$ dependability is $3305.5 \mathrm{MCM}$ annually, with only 542.1 MCM during non-monsoon season, that includes rainfall runoff, field irrigation runoff and base flows.

b) Imported water from other river basin to Gomti basin at $75 \%$ dependability

\section{Diversion from Sharda river 2487.6 MCM}

Diversion from Ghaghara river 7091.7 MCM

\section{c) Groundwater availability}

Annual replenishable groundwater resource 10283 MCM

Hence presently, total utilizable water resources in Gomti basin is $23167.8 \mathrm{MCM},(\mathrm{a}+\mathrm{b}+\mathrm{c})$ against total water resources availability in Gomti basin 38647.51 MCM at $75 \%$ dependability.

Table 12

Total Available Water Resources In Gomti Basin

\begin{tabular}{|c|c|c|c|c|c|}
\hline \multirow{2}{*}{ Property } & \multicolumn{5}{|c|}{ Dependability Level } \\
\hline & Mean & $25 \%$ & $50 \%$ & $75 \%$ & $90 \%$ \\
\hline $\begin{array}{l}\text { Local Surface } \\
\text { Water } \\
\text { (generated } \\
\text { within basin), } \\
\mathrm{Mm}^{3} / \mathrm{yr}\end{array}$ & $9,889.29$ & $11,851.19$ & $9,654.05$ & $7,485.66$ & $6,036.94$ \\
\hline $\begin{array}{l}\text { Imported from } \\
\text { Banbasa } \\
\text { Barrage, } \\
\mathrm{Mm}^{3} / \mathrm{yr}\end{array}$ & $8,251.03$ & $9,592.78$ & $7,506.29$ & $7,120.26$ & $6,529.54$ \\
\hline $\begin{array}{l}\text { Imported from } \\
\text { Lower Sharda } \\
\text { Barrage } \\
\text { (including } \\
\text { inflow from } \\
\text { Girija Barrage), } \\
\mathrm{Mm}^{3} / \mathrm{yr}\end{array}$ & $20,347.31$ & $24,104.53$ & $16,416.1$ & $13,758.6$ & $12,360.8$ \\
\hline $\begin{array}{l}\text { Dynamic } \\
\text { Groundwater, } \\
\mathrm{Mm}^{3} / \mathrm{yr}\end{array}$ & $10,283.00$ & $10,283.00$ & $10,283.0$ & $10,283.0$ & $10,283.0$ \\
\hline $\begin{array}{l}\text { Total Available } \\
\text { Water, } \mathrm{Mm}^{3} / \mathrm{yr}\end{array}$ & $48,770.63$ & $55,831.50$ & $43,859.5$ & $38,647.5$ & $35,210.3$ \\
\hline
\end{tabular}




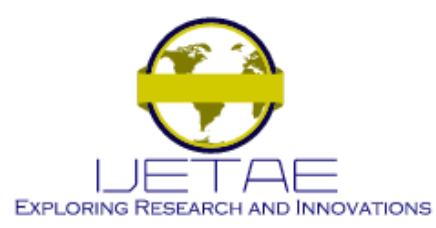

International Journal of Emerging Technology and Advanced Engineering

Website: www.ijetae.com (ISSN 2250-2459, ISO 9001:2008 Certified Journal, Volume 10, Issue 11, November 2020)

Allocation of E-Flow in Gomti Basin

TABLE 13 AVERAGE AND 75\% DEPENDABLE VIRGIN, OBSERVED AND E- FLOWS IN GOMTI RIVER AT MAIGHAT

\begin{tabular}{|l|c|c|c|c|c|c|c|c|c|c|c|c|c|}
\hline $\begin{array}{l}\text { Flow Volume, } \\
\text { MCM }\end{array}$ & Jan & Feb & Mar & Apr & May & Jun & Jul & Aug & Sep & Oct & Nov & Dec & Annual \\
\hline $\begin{array}{l}\text { Virgin Flow } \\
\text { Average }\end{array}$ & 277.07 & 175.27 & 106.89 & 67.80 & 49.99 & 183.16 & 1621.93 & 2564.75 & 2382.00 & 1331.61 & 698.04 & 430.78 & 9889.29 \\
\hline $\begin{array}{l}\text { Observed Flow } \\
\text { Average }\end{array}$ & 361.29 & 260.68 & 230.29 & 163.45 & 118.43 & 210.80 & 779.16 & 1322.58 & 1534.19 & 1126.03 & 470.94 & 386.51 & 6964.35 \\
\hline $\begin{array}{l}\text { E-flows as at } \\
\text { Jaunpur }\end{array}$ & 386 & 310 & 327 & 280 & 268 & 388.5 & 761.12 & 1385.56 & 2061.64 & 1251.56 & 546 & 426.12 & 8391.35 \\
\hline $\begin{array}{l}\text { Virgin Flow } \\
\text { @75\% depend }\end{array}$ & 209.73 & 103.67 & 80.91 & 51.32 & 37.84 & 138.64 & 1227.71 & 1941.38 & 1803.05 & 1007.96 & 528.38 & 326.08 & $7,485.66$ \\
\hline $\begin{array}{l}\text { Observed Flow } \\
\text { @ 75\% depend }\end{array}$ & 280.9 & 200.8 & 177.8 & 125 & 89.2 & 137.5 & 393.2 & 640.5 & 1023.7 & 568.5 & 279.4 & 264 & 3305.5 \\
\hline
\end{tabular}

The average monthly and $75 \%$ dependable virgin flow, observed flow and recommended e-flow (as at Jaunpur) has been tabulated in Table 13 for Gomti Basin at Maighat. The annual E-flow volume is $8391.35 \mathrm{MCM}$ which is $84.85 \%$ of average virgin flow, $120.53 \%$ of average observed flow. E-flows volume is respectively $112.09 \%$ of virgin flow and $253.86 \%$ of observed flow at $75 \%$ dependability. E-flows as compared with average and at 75\% dependable flow are shown in Figure 17.

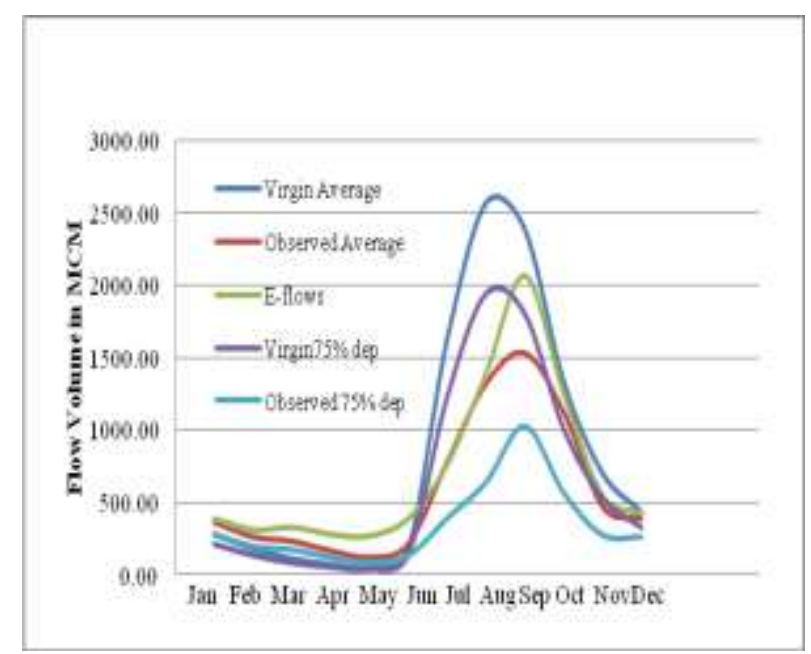

Figure 17. Virgin, Observed And E-Flows Volume For Gomti River At Maighat D/S Jaunpur- Av. Vs 75\% Dependability
It is clear from Figure 17 that recommended e-flows for Jaunpur site is even higher than virgin and observed flow volume at Maighat, a site downstream of Jaunpur the last one on Gomti river prior it merges into Ganga. For the rest of the months e-flows are within average virgin flow volume. It is suggested that relook in e-flows numbers require more study.

\section{TOWARdS E-FLOWS IMPLEMENTATION - NEXT STEPS}

In comparison to E-Flows assessment, the E-Flows implementation has always been a much more complex, challenging and time-intensive task; this phenomena gets even more cumbersome in case of committed river systems (whose water resources are committed/allocated to various uses, including - irrigation, domestic supplies and industrial use).

The surface water of Gomti Basin is used as raw source for domestic water supply for major urban centers and for irrigation through minor irrigation schemes. To meet the growing demand of water of Lucknow city, Gomti river waters are being used. During summer months, river is almost dried up. Therefore, to meet the domestic water supply of Lucknow city, 150 cusec of water is made available from Lucknow branch of Sharda canal system through Mahdoiya escape in to Gomti River during May and June. A pumping station is built at Gaughat on Gomti River to lift this water for supply to old city area. For transGomti area of Lucknow city, 50 cusec of water is pumped from Sharda Sahayak feeder to Kathauta Jheel. From here, water is supplied to this area. 


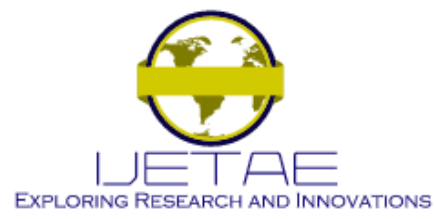

International Journal of Emerging Technology and Advanced Engineering

Website: www.ijetae.com (ISSN 2250-2459, ISO 9001:2008 Certified Journal, Volume 10, Issue 11, November 2020)

Besides Lucknow, Gomti River supplies domestic water to Sultanpur and Jaunpur town. Further, there are 71 minor lift irrigation schemes in Gomti basin, 25 on Gomti river, 23 on Sai river, 9 on Sarayan river, 6 on Kathna river, 5 on Kalyani river and 3 on Pirai river having total capacity of 1458 cusecs and CCA of 35,445 ha. But their running capacity has dropped to $50 \%$, due to non-availability of sufficient power and water. In Gomti basin, domestic and industrial water supplies are mainly dependent on ground water.

Gomti Basin is water short and unable to meet present and future water demand of 15068 MCM (2015), 16823 MCM (2025), 18442 MCM (2035) and 18468MCM (2045). Non-agricultural Water demand in Gomti Basin is given in Table 14 and Figure.17. Growth of Nonagricultural water demand from $16 \%$ of water use in 2015 to $23 \%$ in 2025 , to $29 \%$ in 2035 and to $32 \%$ in 2045 as shown in Figure 18[TAHAL, 2020\}.

Table 14

Non-Agricultural Demands, MCM

\begin{tabular}{|l|l|l|l|l|}
\hline \multicolumn{1}{|c|}{$\begin{array}{l}\text { Water } \\
\text { Demand }\end{array}$} & $2014-15$ & $2024-25$ & $2034-35$ & $2044-45$ \\
\hline Urban Domestic & 357.62 & 457.74 & 511.87 & 548.36 \\
\hline Rural Domestic & 388.66 & 607.76 & 889.66 & 997.57 \\
\hline Livestock & 163.62 & 179.53 & 197.01 & 214.49 \\
\hline $\begin{array}{l}\text { Industrial Non- } \\
\text { Agricultural }\end{array}$ & 343.57 & 1308.78 & 1692.37 & 1884.34 \\
\hline
\end{tabular}

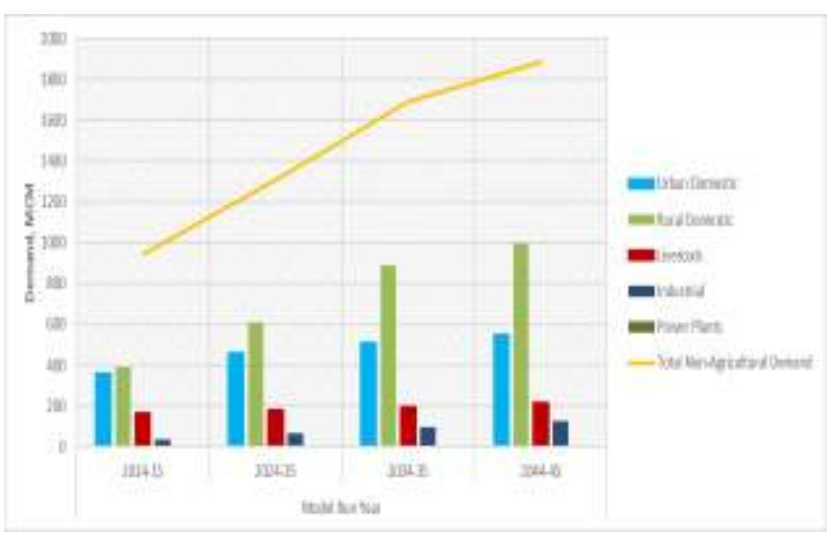

Figure 17 Non-Agricultural Demands, MCM

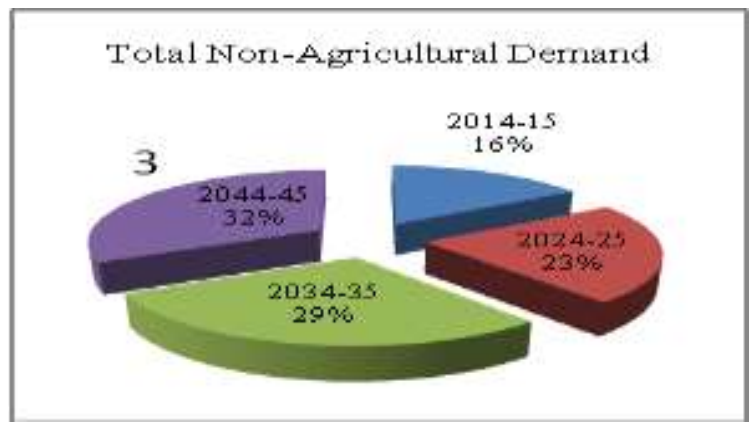

Figure 18 Non-Agricultural Demand Growth, \%

\section{Agricultural Water Demands}

Considering three agricultural scenario given below as AGP-1, AGP-2 and AGP-3 Agricultural water demand estimated is given in Table-15 and is shown in Figure 19.

- AGP-1: Projected Crop Areas as per the prevailing Trend (BAU)

- AGP-2: Proposed Crop Areas as per past Trend for increasing crops(replacing paddy by SRI gradually and keeping other decreasing crops constant

- AGP-3: Proposed Crop Areas, a shift in Rice area from traditional method to SRI method by $20 \%, 30 \%$ and $40 \%$ in year 2025, 2035 and 2045, respectively has been considered. Also conversion of $10 \%$ area to micro-irrigation has been considered.

\begin{tabular}{|l|l|l|l|l|}
\hline \multicolumn{5}{|c|}{ Table 15 Agricultural Water Demand In Gomti Basin } \\
\hline $\begin{array}{l}\text { Agricultural } \\
\text { Demand }\end{array}$ & $2014-15$ & $2024-25$ & $2034-35$ & $2044-45$ \\
\hline AGP-1 & $14,123.54$ & $15,514.41$ & $16,750.31$ & $17,584.00$ \\
\hline AGP-2 & $14,123.54$ & $15,373.71$ & $16,253.64$ & $16,280.45$ \\
\hline AGP-3 & $14,123.54$ & $14,332.88$ & $14,298.48$ & $14,104.85$ \\
\hline
\end{tabular}

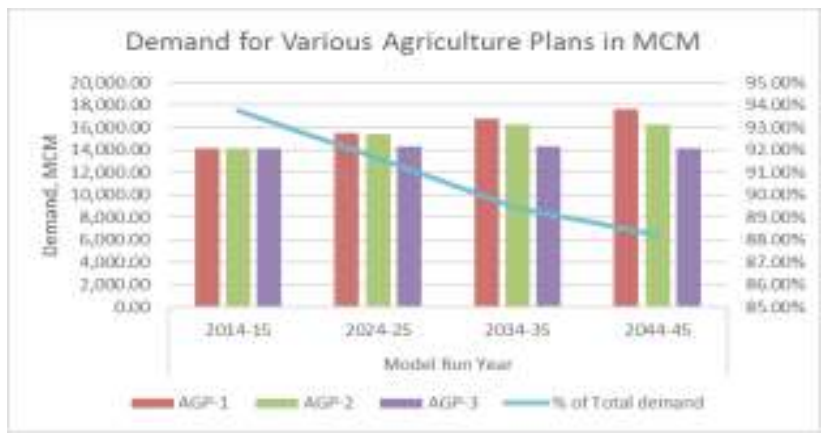

Figure 19 Agricultural Water Demands In Gomti Basin (Mcm) By 2015, 2025, $2035 \& 2045$ 


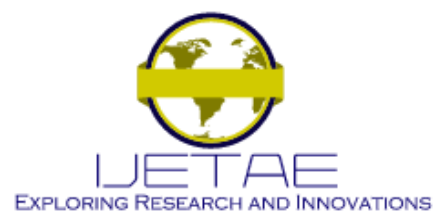

International Journal of Emerging Technology and Advanced Engineering Website: www.ijetae.com (ISSN 2250-2459, ISO 9001:2008 Certified Journal, Volume 10, Issue 11, November 2020)

It is evident from Figure 19 that agriculture water use share in overall water use is decreasing from $94 \%$ in 2015 to $88 \%$ by 2045 in the Gomti Basin. The total sect oral water demand is shown in Figure 20.

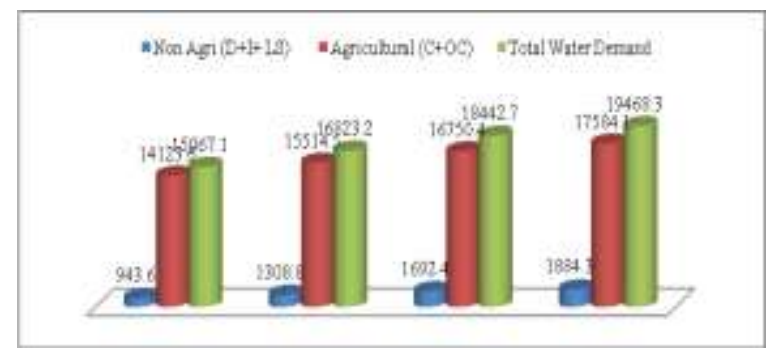

Figure 20 Sectoral Water Demands In Gomti Basin (Mcm) By 2015, $2025,2035 \& 2045$

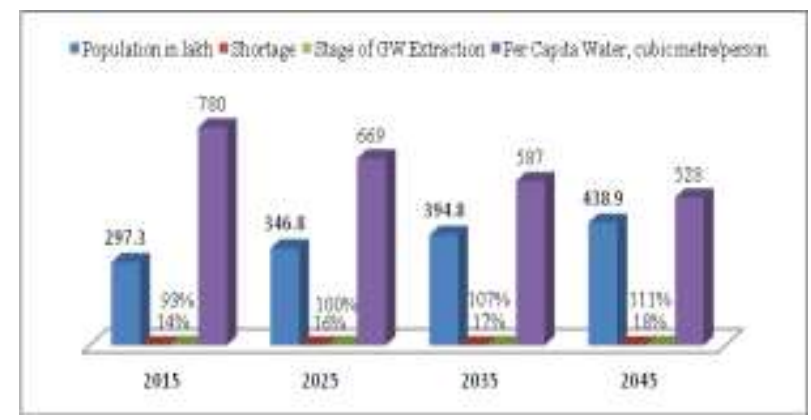

Figure 21 Gomti Basin Population, Per Capita Water, Unmet Agri Demand \& Stage Of Gw Extraction BAU

As shown in Figure 21, in Gomti Basin per capita water availability is $780 \mathrm{~m}^{3} /$ person, this means water scarcity situation prevails in the basin due to population density (882 person/sq. $\mathrm{km}$ ) being more than 3 times of the India (382 person/sq.km). This is the situation while inter basin water transfer is meeting the most of command irrigation since nineteenth century.

River Gomti has been one of the most critical rivers, when it comes to E-Flows implementation, primarily because this one is a groundwater fed river, with no real storage (except one at Lucknow, but that is a barrage only) on it. This means that, any additional flows requirement in wake of E-Flows recommendations will have to take into account fairly complex and tough decisions.

The implementation of E-Flows will have to take into account the concerns and issues of the water resources institutions - as they are the ones who deal with water resources planning, allocation, distribution and use. Therefore, these E-Flows recommendations are required to be deliberated upon with various stakeholders, especially the water resources managers. This will facilitate the buy-in from them and therefore, aid in E-Flows implementation.
The storages and diversions alone are not the answer to maintaining E-Flows regime in such river systems; the heavy reliance on groundwater and therefore unregulated groundwater exploitation is another critical issue that needs to be tackled, if E-Flows, are to be maintained in the river systems in a sustainable manner.

Assessment of human interventions and its impacts on hydrological regime of river Gomti by the author [Ravindra, et al. 2015] informs that,

a. Drainage congestion and encroachment in the upper segment: The upper stretch of the river is heavily encroached by agricultural fields and has sluggish flow condition. As per revenue records, encroachment into the river and its floodplain has left limited fields in the name of Gomti river in each village in the upper stretches. The upper and middle segment of the river is severely affected by flooding during monsoon due to drainage congestion. Deforestation along the banks has also led to run-off depositing silt in the stream bed leading to low channel capacity.

b. Extensive exploration of groundwater: The unregulated groundwater exploitation has contributed significantly to reduction of flows in river Gomti. As part of the water cycle, groundwater is a major contributor to Gomti river's flow and its tributaries. The precipitation during the monsoon season is the dominant source of water for groundwater recharge in the GRB. If extent of extraction is lowered to river bed depth, the maintenance of ecological flow becomes difficult in that reach.

c. Reduction in forest cover and wetlands: There has been severe reduction in forest cover and wetlands in the entire Gomti basin due to rapid land-use change and increasing demand of land for urbanization. This has affected the flow of water in Gomti river, as most of the tributaries originate from water bodies or forests and reduction in their density has caused reduction in water availability in the river. Except Pilibhit and Kheri districts, all the districts falling under the basin are deficient in forest cover. LANDSAT satellite data of 1978 and IRS-1C/LISS III sensor data of 2008 shows that, built-up area has increased while the forest and plantation area including water bodies has decreased. There is no flow in the initial $57 \mathrm{~km}$ stretch of the river with wide encroachment of active floodplains.

In another study conducted by author ' impact of river channelization and riverfront development on fluvial ecology: evidence from Gomti river' authors made assessment of the loss of river process and ecosystems under changed hydraulic regimes post RFD. 


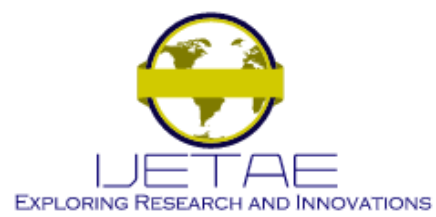

International Journal of Emerging Technology and Advanced Engineering

Website: www.ijetae.com (ISSN 2250-2459, ISO 9001:2008 Certified Journal, Volume 10, Issue 11, November 2020)

They observed eight types of habitat in the undisturbed segments of the Gomti river, while only two habitat types were present in the channelized segments. The paper argues that, due to heavy channel engineering led river front development and other related morphometric changes, there would be decline in freshwater species and water quality, lowering of groundwater tables in the city reach resulting from diminishing base flow and flooding of the downstream areas. "The reduction in flow, in the absence of water augmentation measures, will further impact the minimum environmental flows required to maintain the healthy ecosystems in the river broadening the area of ecological disturbances."

Maintaining E-Flows in Gomti river would be a complex proposition. Nevertheless, it is a lifeline for the cities, towns and villages through which it passes; therefore, for a larger cause, the health of Gomti river needs to be improved.

The present day flows at all the location (except first location, i.e. Mehndi Ghat and that is mainly because of the barrage at downstream of this site) on Gomti river does not meet E-Flows requirements due to the reasons discussed above. The E-Flows maintenance in Gomti river would therefore require massive interventions in regard to catchment area treatment, ground-water regulation through promoting water use efficiency across all water-using sectors, including - irrigation. Whilst the barrage at Lucknow, will play some role in maintaining E-Flows in first two E-Flows sites around Lucknow city; but the groundwater management will hold the key.

Urban water demand by Lucknow city is envisaged total 1281 MLD by 2040 for the projected population of 5.6 million. The existing 3 water works (Aishbag, Balaganj \& Gomtinagar) use 575 MLD surface water (from Gomti 475 MLD and 80 MLD from SS Feeder Canal). Shifting groundwater supply (from existing $47.90 \%$ to $25 \%$ ) to surface water supply (increased from existing $52.10 \%$ to $75 \%$ use ) means demand of 1001 MLD from current 575 MLD that a gap of 426 MLD has to come from augmenting Gomti river flows by near by irrigation canal systems in an attempt to guarantee the water availability of 500 MLD in all seasons..
The merit and demerit of various options to augment Gomti river flows namely- (i) lifting of water from Ganga river at Lava-Kush barrage Kanpur, $80 \mathrm{~km}$ away; (ii) pumping water from Ghaghara river at Elgin bridge Barabanki,60 km away; (iii) lifting water from Sharda Sahayak Feeder at $\mathrm{km} 65$ to Kheri branch (11km pipe) through Munderi escape to Gond -Sarayan (tributaries) to Gomti river, (iv) lifting water from SS Feeder km 104.0 (27 $\mathrm{km}$ pipe) connecting Ateria escape of Kheri branch to Gomti river; and (v) by gravity flow connecting SSF km 140.78 by $20 \mathrm{~km}$ pipe line directly to Gomti river, near bridge at Lucknow-Sitapur Ring Roa and has been studied and reported by authour [Ravindra, 2019].

It has been agreed that gravity flow option is economically feasible by connecting SSF at $140.78 \mathrm{~km}$ directly to Gomti river) and UP Jal Nigam have been directed to prepare DPR for upcoming Water Works at Alambagh and Indira Nagar.

It is recommended to augment Gomti river flows from Sharda Shayak canal system, off taking from Ghaghara river by gravity flow through $20 \mathrm{~km}$ pipeline from chain age $140.78 \mathrm{~km}$ to outfall $2 \mathrm{~km}$ upstream of Gaughat near Lucknow-Sitapur Road bridge, as shown in bottom of Figure 23.

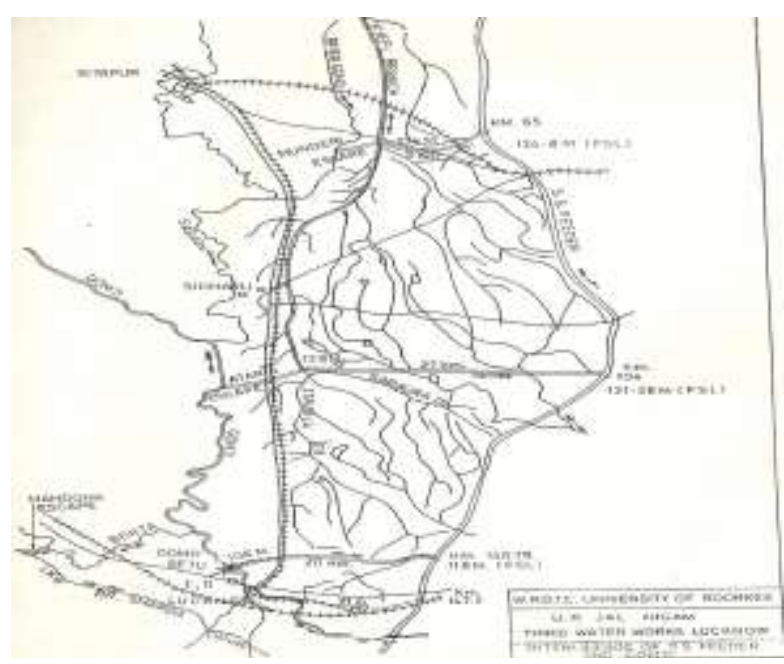

Figure 23 Sarda Sahayak Feeder Link To Gomti River From Chainage $140.78 \mathrm{Km}$. Figure 24 Gomti Escape Link 


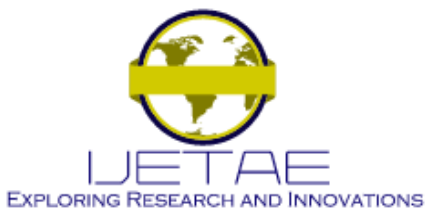

International Journal of Emerging Technology and Advanced Engineering

Website: www.ijetae.com (ISSN 2250-2459, ISO 9001:2008 Certified Journal, Volume 10, Issue 11, November 2020)

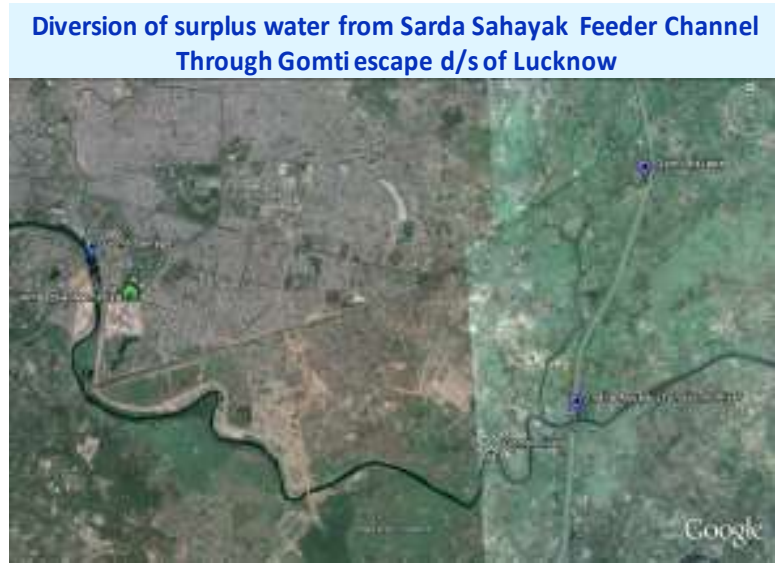

Figure 24 Ssfeeder Link Through Gomti Escape To Gomti River U/S Aqueduct

Augmentation of minimum flows in Gomti river d/s Lucknow during 15th Jan to 15th June diversion of surface water from Sharda Sahayak Feeder Canal through Gomti escape to outfall upstream of Indira Aqueduct is recommended through Gomti escape of S.S. Feeder as shown in Figure 24.

\section{Gomti Flows Augmentation at Origin:}

Government of Uttar Pradesh has plan further to augment Gomti river flows at Origin (Fulhar Jheel / Gomat Taal through Devipur minor of Madhotanda distributary of Sharda canal), $450 \mathrm{~km}$ away from Lucknow (Figure 25) ensuring longitudinal connectivity in Gomti river by providing environmental flows requirement and towards development for navigation around Lucknow

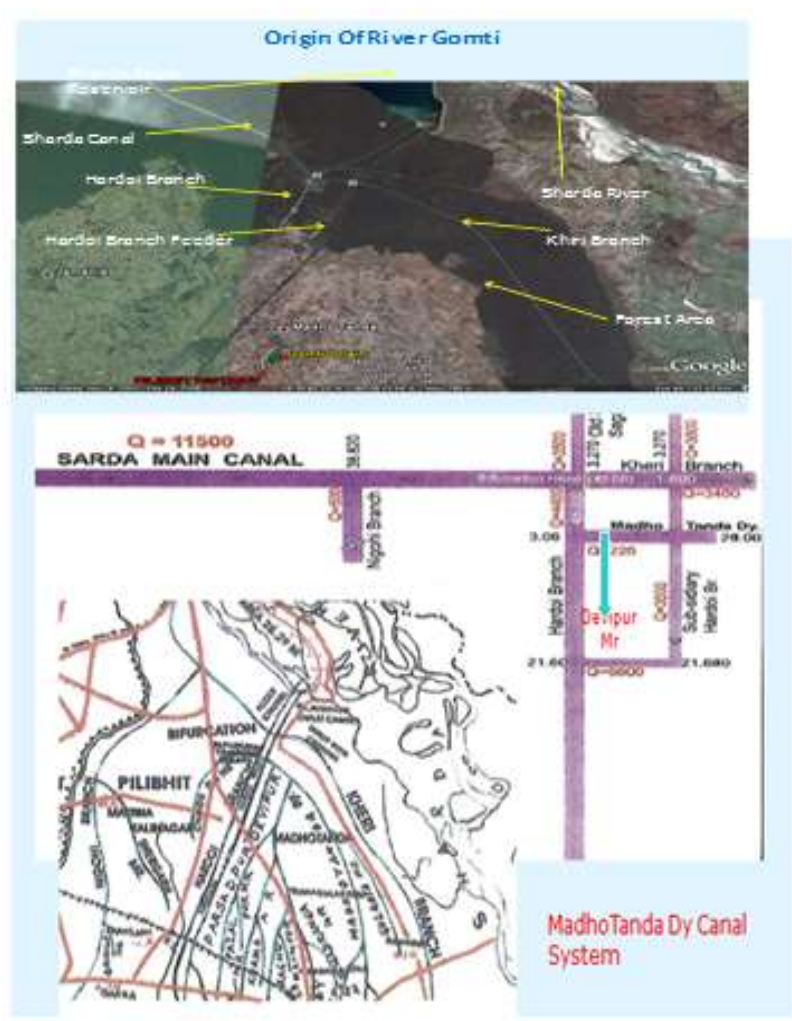

Figure-25 Linking Devipur Minor Of Madho Tanda Dy To Fulher Jheel (Gomat Tal)- The Origin Of Gomti River

Base Flows Augmentation: Recharge from Water Harvesting in Gomti Basin

Watershed and Wetlands development and Rooftop rainwater harvesting could recharge $100 \mathrm{MCM}$ at conservative estimate as detailed in Table-16.

\begin{tabular}{|l|l|l|l|l|l|l|l|}
\hline \multicolumn{7}{|c|}{ TABLE 16 GROUNDWATER RECHARGE AUGMENTATION.IN GOMTI BASIN DURING 15 YEARS TIME SPAN } \\
\hline $\begin{array}{l}\text { S. } \\
\text { N }\end{array}$ & $\begin{array}{l}\text { Cost. in } \\
\text { Cr. Rs. }\end{array}$ & Area & Unit & $\begin{array}{l}\text { Rates } \\
\text { in Rs. }\end{array}$ & $\begin{array}{l}\text { Recharge in } \\
\text { MCM }\end{array}$ & Remarks \\
\hline 1 & Watershed Development & 269.2 & 53844 & ha & 5000 & 9.69 & Area with $\%$ additional rainfall recharge \\
\hline 2 & Wetland Development & 1646.6 & 44263 & ha & 5000 & 74.36 & On $60 \%$ area, 1.4 mm per day for 200 days \\
\hline 3 & Roof Top Harvesting & 1120.6 & 22870000 & $\mathrm{~m}^{2}$ & 490 & 16.01 & Limited to five major cities in $10 \%$ roof areas. \\
\hline & Total & 3036.4 & & & & 100.06 & \\
\hline
\end{tabular}




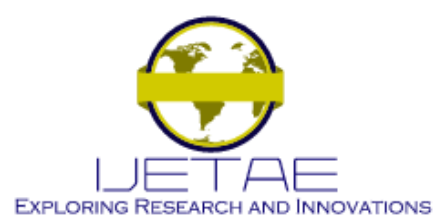

\section{International Journal of Emerging Technology and Advanced Engineering Website: www.ijetae.com (ISSN 2250-2459, ISO 9001:2008 Certified Journal, Volume 10, Issue 11, November 2020)}

\section{INVESTMENT SUMMARY FOR GOMTI BASIN}

Gomti River is water short at times in quantity and quality, its flows has to be augmented by water transfer from other river basins such as Sharda/Ghaghara. Water transfer from Ganga River is not cost effective and sustainable. Ensuring groundwater recharge to enhance base flows and environmental flows of Gomti River is required for sustainability of the water resources and good health of the river. The investment to be made in Gomti Basin for improvement in water use efficiency in Agriculture sector and recharging groundwater is of the order of INR10,396.23 Crores. Formation and strengthening of WUAs $240.69 \mathrm{cr}$, removing canal system deficiencies1,245.06 cr, removing drainage system deficiencies $1,546.42 \mathrm{cr}$, shallow tubewell Installations $309.10 \mathrm{cr}$, watershed development $269.22 \mathrm{cr}$, sodic land reclamation $471.51 \mathrm{cr}$, wetland development $1,646.57 \mathrm{cr}$, waste water treatment $710.26 \mathrm{cr}$, roof top harvesting $1,372.70 \mathrm{cr}$, micro irrigation $1,045.07 \mathrm{cr}$, CAD\&WM works 1,045.07 cr, and miscellaneous@5\% INR 495.06 cr.

\section{CONCLUSIONS}

E-Flows assessment, like any other robust E-Flows assessment process, has been a socio-technical and scientific process, but considering all practical natural boundaries (in terms of possibilities of flows) of a given river. While e-flows assessment for Gomti River has been preliminary estimated at four sites (i) two sites around Lucknow city, one upstream of Gomti Barrage and another $\mathrm{d} / \mathrm{s}$ of Gomtinagar, (ii) Sultanpur and (iii) Jaunpur. Recommended E-flows are compared with virgin and observed flow at e-f sites. It is concluded that some refinement is required in future studies. Implementation issues of E-flow has been discussed in length. It is suggested that to implement e-Flows, backup efforts have to be made so that water could be freed from irrigation sector and let a minimum allocation of E-flows mandated in Gomti river and then move to required E-flows as estimated by experts and agreed by stakeholders. Water harvesting, conservation and sub surface storage by ensuring base flows to sustain river flows during lean flow months. This is very important for groundwater fed river like Gomti. A summary of investment over 15 years span has been given to recover $100 \mathrm{MCM}$ rainwater at cost of INR 10,000 crores

Flows augmentation at origin of Gomti river is one good response of UP government and community in Pilibhit. River corridor has been demarked in government records and river cross section released in Pilibhit and Shahjahanpur district dovetailing MANREGA funds.
To Augment flows in Gomti River around Lucknow City, gravity flow option is economically feasible by connecting S.S. Feeder Canal off- taking from Girja barrage on Ghaghara river, from $140.78 \mathrm{~km}$ by underground $20 \mathrm{~km}$ pipeline to Gomti river, near upstream of Lucknow- Sitapur road bridge.

\section{Acknowledgement}

The author is thankful to WWF-India, New Delhi for providing opportunity to work with them as partner in their project "E-flows Assessment of Major rivers of Uttar Pradesh". Special thanks are due to Mr Nitin Kaushal Associate Director, SWM, WWF for sharing draft report including the starter documents prepared by thematic groups for comments. The author once again thanks all researchers whose work has been referred here.

\section{REFERENCE}

[1] Alam et al, 2020, Starter document Aquatic biodiversity for major rivers of Uttar Pradesh, WWF-India, New Delhi, \& ICAR-NBFGR.

[2] Dutta V., Kumar R, Sharma U, 2015, Assessment of human induced impacts on hydrological regime of Gomti river basin, India, Manag. Environ Quality Int. J 26(5)631-649..

[3] Dutta V., Urvashi Sharma, K Iqbal, Adeeba, Raindra K, A.K. Pathak, 2018, Impact of river channelization and river front development on Fluvial ecology: evidence from Gomti River, a tributary of Ganges, India, J. Environmental Sustainability, Springer. Accepted 7 July 2018. This paper may be assessed at https://doi.org/10.1007/s42398-018-0016-0

[4] Dutta V, Kumar R, Yunus M, Ahmad S, Pathak VV, Rai A and Prasad N, 2011, Restoration Plan of Gomti River with Designated Best Use Classification of Surface Water Quality based on River Expedition, Monitoring and Quality Assessment, Earth Science India, j Vol 4 (iii) July 2011, pp 80-104

[5] GFCC, MoWR, GOI, 2004, Compendium of Guidelines in the field of Flood Management.

[6] King J,Tharne RL, and de Villiers M.S., 2008, Environmental flow assessments for rivers: manual for the Building Block Methodology.

[7] Ravindra Kumar, 2018, Assessment of Environmental Sustainability of a large alluvial river in central Ganga Basin-India, Case study of Gomti river Post River Front Development Works. Proc of CV, IEI, Ahemdabad, Gujrat, 2019.

[8] Rajiv Sinha, 2020, Starter Document, Morphological study of major rivers of Uttar Pradesh for WWF-India.

[9] Ravindra Kumar, 2019, Sustainable Water Supply Plan-2040 for Lucknow City, J IWWA, Oct-Dec. 2019.

[10] SWaRA, GOUP, 2020, Gomti Basin Plan prepared by TAHAL Consulting Engineers Ltd, Israel/India for State Water Resources Agency, Government of Uttar Pradesh.

[11] Vaughan I.P., Diamond M, Gurnell A.M., Hall KA, Jenkins a., Milner NJ Nayler LA, Sear, DA, Woodward G, and Ormerod S.L., 2008, Integrating ecology with hydromorphology: a priority for river science and management, Aquatic Conservation: Marine and Freshwater Ecosystem, 19, 113-125 (2009), Pub. Jihn Wiley \& Sons Ltd.

[12] WWF-India, 2020, Environmental Flows Assessment of Major Rivers of Uttar Pradesh. 